\title{
The
}

\section{Volta Resettlement}

\section{Experience}

\author{
edited by \\ ROBERT GHAMBERS
}

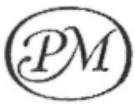

PALL MALL PRESS

LONDON

in association with

Volta River Authority University of Science and Technology Accra Kumasi

INSTITUTE
OR
DEVELOPMENT
STUDIES
LIBRART


Published by the Pall Mall Press Ltd

5 Cromwell Place, London sw7

FIRST PUBLISHED I 970

(C) Pall Mall Press, I970

SBN 269025979

Printed in Great Britain by

Western Printing Services Ltd

Bristol 


\section{GONTENTS}

PREFACE

xiii

FOREWORD

SIR ROBERT JAGKSON

I. INTRODUGTION

IO

ROBERT GHAMBERS

The Preparatory Commission Policy: Self-Help with Incentives, 12

Precedents, Pressures and Delays, I956-62, I 7

Formulating a New Policy, 196I-63, 24

2. THE ORGANISATION OF RESETTLEMENT

E. A. K. KALITSI

Organisation and Staffing, 35

Evolution of Policy, 39

Housing and compensation policy, 39; Agricultural policy, 4I ;

Regional planning policy, 42

Execution, 44

Demarcation, 44; Valuation, 45; Social survey, 46; Site selection, 49; Clearing and construction, 52; Evacuation, 53;

Farming, 55

Costs and Achievements, 56

3. VALUATION, ACQUISITION AND COMPENSATION

FOR PURPOSES OF RESETTLEMENT

K. AMANFO SAGOE

Scope and Scale of the Exercise, 59

Public and Private Rights Affected, 6I

Ethical and Legal Bases for the Government's

Compensation Policies, 64

Valuation and Compensation for Land, Crops and

Buildings, 67

Proposals for Policy in Resettlements, 72

Conclusion, 75 
4. THE SOGIAL SURVEY

D. A. P. BUTCHER

Purposes and Preparation, 78

Executing the Survey, 80

Processing and Analysis of Data, 82

Immediate Usefulness, 83

Future Uses for the Survey Data, 86

Social Aspects of Housing and the New Towns, 88

Conclusion, 90

5. SOGIAL WELFARE

G. W. AMARTEIFIO

Social Welfare Participation, I04

Previous Resettlement Experience: Frafra and Tema, I05

Recruitment and Training of Staff, 108

Roles of the Social Welfare Resettlement Unit, I I I

Problems of Site Selection and Regrouping Villages, I I 3

Propitiation and Libation, I 6

Evacuation Problems, I I 7

Post-Evacuation and Town Development, I 8

Conclusions, I I 9

APPENDIX I: Questions Asked by the Villagers, I 2 I

APPENDIX II: Some Letters Received by the

Resettlement Officer, I25

APPEN DIX III: Letters Concerning Libations, I 33

A P PENDIX IV: Documents Issued to the People Affected, I 4I

A P PENDIX V: Resettlement Sites and Statistics, I45

APPENDIX VI: Summary of Households for New

Resettlement Sites, September 30, I964, I 47

6. RESETTLEMENT PLANNING

LASZLO HUSZAR

Volta Basin Plan, ${ }^{8} 8$

Area Plans, I 49

Location of Sites, 152

Settlement Sizes and Services, I 53

Plot Sizes and Population Densities, I 57

Planning the Housing Layout, I6o

Planning Limitations, I6 I 
7. HOUSE DESIGN

MILES DANBY

Problems and Policies, 164

House Designs, 166

Evaluation, 17 I

Future Developments, i 76

General Observations, I 77

8. THE ENGINEERING PROGRAMME

AND PROBLEMS

T. S. JOHNSON

Tasks and Organisation, 179

Road Construction and Land Clearing, 180

Water Supplies, I83

House Construction, 186

Conclusion, 190

9. A GASE STUDY OF A RESETTLEMENT TOWN:

NEW MPAMU

MARTHA DODOO

Physical Characteristics of New Mpamu, 194

The People of New Mpamu, I95

Attitudes Towards the Physical Environment, 196

Social and Administrative Problems, 199

IO. RESETTLEMENT AGRIGULTURE

M. S. O. NICHOLAS

Policy and Organisation, 205

Information and Surveys, 207

Agricultural Planning, 208

Implementation and Progress, 2 I I

Problems and Lessons, 213

I I. PRESENT AND FUTURE PROBLEMS OF

ADMINISTERING RESETTLEMENT TOWNS

E. A. K. KALITSI

Who Administers the New Settlements? 217

Town Managers, 218

Agriculture, 220

Social Cohesion, 220

Implementation of Town and Building Standards, 221 


\section{CONTENTS}

Permissiveness versus Limited Capacity, 222

Can We Keep the People in the Resettlement

Towns? 223

12. POSTSCRIPT AND DISGUSSION

ROBERT GHAMBERS

Postscript: The Resettlement Programme, 1965-68

Social Welfare and the Resettlement Towns, 227

Agriculture, Land and the World Food Program, 233

Settlers' Experience and Reactions, 240

Mid-1968: Taking Stock, 245

Concluding Discussion

Social and Economic Policies, 252

Organisation, Staffing and Style, 255

Opportunities for Development, 258

Timing and Costs, 26o

Constraints and Choices, 263

Conclusion, 267

GONTRIBUTORS

BIBLIOGRAPHY 


\section{PREFACE}

The Volta Resettement Symposium was held at the University of Science and Technology, Kumasi, from March 2 I to 27,1965 . It was sponsored jointly by the Volta River Authority and the Faculty of Architecture of the University. The convening committee consisted of Dr D. A. P. Butcher, Research Fellow in Sociology in the Research Department of the Faculty of Architecture; Mr E. A. K. Kalitsi, Resettlement Officer of the Volta River Authority; Professor J. R. Lloyd, Dean of the Faculty of Architecture; and Mr H. F. Winful, Executive Secretary of the Volta River Authority. The detailed organisation at Kumasi was undertaken by the Research Department of the Faculty of Architecture, and travel arrangements for participants were made by the Volta River Authority. The Symposium was attended by over I $5^{\circ}$ people from at least seven countries, and thirteen papers were presented, most of them by authors who had been directly involved in the resettlement operation. These papers were mimeographed in an unedited form and reissued as "Volta Resettlement Symposium Papers" in June I965. Demand for them soon outstripped supply, and this led to a series of initiatives by the Volta River Authority to secure editing and more permanent publication. This has eventually been made possible through support from the Food and Agriculture Organisation of the United Nations, acting through the Volta Lake Research Project.

In selecting, editing and shortening the papers I have been given a free hand. For this I am indebted to Mr E. L. Quartey, the Chief Executive of the Volta River Authority, who invited me to carry out the task, and to the Vice-Ghancellor of the University of Science and Technology, Kumasi, who approved the arrangements. I have tried to concentrate attention on the practical experience of the resettlement programme. I also felt that, if there were major revisions based on events subsequent to March 1965 , some of the freshness and immediacy of the papers would be lost. I therefore asked the contributors 
to exercise forbearance and to allow the substance of what they had written to stand, regardless of what had happened since. I should like to thank them all most warmly for accepting this approach, agreeing to almost all editorial revisions, and communicating promptly as we have proceeded. Few editors can have had such co-operative and efficient contributors. Delays have been partly my responsibility, and I owe all concerned an apology that the final work of editing was not completed earlier.

In writing the last chapter I have had the benefit of hindsight denied to the contributors. To have edited the papers without bringing events up to date and trying to analyse some of the major issues raised by the experience would, I think, have been to shirk a proper responsibility. At the same time, I have been pulled in one direction by the temptation to make easy criticisms based on the obvious problems that have arisen, and in the opposite direction by a sense of awe at the difficulties of the resettlement operation and the boldness and imagination with which they were tackled. I cannot expect that the resulting interpretation is balanced; I can only say that I have tried to make it so.

The first and last chapters differ from the rest in having been written by someone who was an outsider to the resettlement programme and who knew little of Ghana. It has been possible to write them only because of the generous help, support and criticism of many people. Sir Robert Jackson was responsible for the suggestion that I should go to Ghana in 1965 and has throughout put his weight behind proposals for publication. Professor W. J. M. Mackenzie has consistently encouraged me and allowed me time for fieldwork and writing. The Food and Agriculture Organisation of the United Nations enabled me to visit Ghana and to carry out other tasks in connection with this book. During my two main periods in Ghana, in 1965 and 1968 , I was given great assistance by the Volta River Authority; and, through reading files, interviewing staff and visiting resettlement towns, I was able to investigate the past and present of the resettlement programme. Those who helped me are too numerous to name, but I hope they will accept my thanks nonetheless. I must, however, mention 
my particular debts to Mr E. A. K. Kalitsi and Mr G. W. Amarteifio for giving up much of their time to long and frank interviews and for making information freely available; to $\mathrm{Dr}$ D. A. P. Butcher for sharing with me his insights and research findings; to Dr B. W. Taylor, Manager of the Volta Lake Research Project, for his guidance; and to Mr Kwame Frempah and $\mathrm{Mr} \mathrm{R}$. W. Amarteifio for making my visits to the resettlement towns as useful and enjoyable as they were.

Detailed comments on earlier versions of the first and last chapters have been made by Mr G. W. Amarteifio, Dr D. A. P. Butcher, Mr C. A. Dadey, Professor Miles Danby, Mr Laszlo Huszar, Sir Robert Jackson, Mr E. A. K. Kalitsi, Mrs Rowena Lawson, Mr D. Paul Lumsden, Mr A. E. G. Markham, Mr R. J. Moxon, Mr Emmanuel Muttukumaru, Mr K. A. Sagoe and Dr B. W. Taylor. As a result I have been able to correct many errors of fact and interpretation. The opinions expressed are, however, mine, and responsibility for them and for mistakes which remain rests with me. Equally, it must be stated on behalf of the contributors that they have written in private capacities and the opinions expressed are their own individually and do not represent those of any organisations for which they have worked.

Throughout the process of producing this book I have been fortunate in being able to benefit from the experience and advice of Mr Ross Pye of the Pall Mall Press. I should like to thank him particularly for his patience, his guidance on many points and the considerable detailed work in which he has been involved in preparing this book for publication. Many other people have also made contributions. The bibliography is the result of suggestions from many sources, but I should like especially to thank Mr Leo Barrington and the Librarian of the Volta River Authority, Mr T. W. Cochrane, for their help. The photographs have been provided by $\mathrm{Mr} \mathrm{G}$. W. Amarteifio (Nos 3, 4, 5, 6, 7 and 8), Mr W. E. Bell (Nos I, 2 and I4), Dr D. A. P. Butcher (No I5), Ghana Information Services (Nos 9 and I9), and the Volta River Authority Public Relations Unit (Nos IO, I I, I 8, 2 I , 23, 27 and 28). The rest of the photos (Nos I 2, I3, I6, I 7, 20, 22, 24, 25, 26, 29 and 30) were taken by me. The maps have been drawn variously by Mr A. I. S. 
Conochie, Mr A. G. Kelly, Mrs E. Mowberry and Mr G. K. Woassey. To Mrs Ljerka Krasevic, who typed most of the text, I am indebted for her prompt and very skilful work, without which my task as editor would have been much more difficult.

Finally, I must state the purpose behind this book. This is not, and has never been conceived as, a public relations exercise on the part of the Volta River Authority. The intention has been to present the experience gained on the Volta so that it may be of use to others. On his appointment in May 1962 , faced with an intimidating task and little time, the Resettlement Officer went to the library of the University of Ghana to see what had been written about approaches to the problem of resettlement. No books on the subject were available. I am sure that all who have contributed to this book and who have made its publication possible hope that such a situation will not recur and that others confronted with similar problems will find something of value in the experience presented here.

Robert Chambers 


\section{I}

\section{Introduction}

\section{ROBERT GHAMBERS}

THE PRIME reason for constructing the Volta dam was to provide cheap hydro-electric power, both for an aluminium smelter to exploit Ghana's large bauxite deposits and for other industrial use, to reduce the country's overdependence on cocoa. The history of the main dam and power project is worthy of study and can be found described elsewhere, ${ }^{1}$ but the programme to resettle the people displaced by the lake formed by the dam has attracted at least as much attention. The exceptional scale and difficulty of the resettlement operation, the new methods devised, the permissive and peaceful evacuation, the new resettlement towns and the rehabilitation and development programmes for the period after evacuation have all aroused widespread interest. This introduction is an attempt to outline the background to the operation, to examine some of the main problems and constraints which had to be faced, and to show how these influenced the evolution of resettlement policies.

The formidable physical difficulties of the operation can be understood from the nature of the basin that was to be flooded. The dam was to be sited near the head of the narrow gorge where the Volta river cuts through the Togo and Akwapim ranges, impounding water from a catchment of 150 ,ooo square miles. The lake to be formed would spread out over the shallow Volta basin to become in area the largest man-made reservoir in the world, covering 3,275 square miles, half the size of Wales or New Jersey, a thirtieth of the surface of Ghana. Not only was the lake basin vast, it was also unhealthy. Insectborne diseases were endemic, with malaria and river-blindness affecting people, and trypanosomiasis affecting cattle. Much

Note: References for this chapter will be found on pages $3^{1-3}$. 
of the basin was also not easy to reach, with difficult terrain and vegetation and with communications that were very poor by national standards. Although the Volta river had in the past carried trade in slaves, salt and other goods, it was broken by rapids and had not developed into a major modern commercial artery. Few roads penetrated the thick tropical rain forests which covered the hills of the south and east, and there were only a few motorable tracks in the savannah woodland of the north. The basin was in the heart of Ghana; but, with the exception of the main road to Kete Krachi (anyway to be cut by the lake), it was isolated, and skirted by the principal lines of communication.

The problems of resettlement were further aggravated by the character and distribution of the people living within the flood basin. There was considerable uncertainty until a late stage about how large the population was; and although the number eventually identified, some 80,000 , was only a little more than one per cent of the population of Ghana, giving a population density much lower than the national average, these people were widely scattered in small communities. Of some $74^{\circ}$ groups, there was only one town (Kete Krachi) of over 4,000 persons, while 600 groups had populations of less than roo. There was unusual ethnic and linguistic diversity. Akwamu, Ewe, Gonja, Krachi, Krobo and Kwahu people were among the most common, but there were also others, including immigrants from Nigeria and Togo. In one small area alone, Akwamu East, it was found that eight languages were spoken. ${ }^{2}$ Moreover, the people were generally poorer and were less well-educated than was usual in Ghana. The Krobo cocoafarmers in the south were exceptional in their relative prosperity, but most of the other inhabitants of the flood basin practised shifting cultivation to achieve little more than subsistence. ${ }^{3}$ Special policy dilemmas were posed by Tongu fishermen*4 and

* Tongu fishermen originated from their 'homes' on the lower reaches of the Volta, but had been settling in the lake basin since at least the last decade of the nineteenth century, and settlement was continuing. Although they often migrated in the course of their fishing, sent their dead 'home' for burial, and usually returned 'home' for annual festivals, many spent most of the year on the river and had established themselves permanently there, and some had even become fulltime farmers. 
Konkomba yam-farmers who had settled in the basin but who often retained other homes and interests elsewhere. From a policy point of view, problems like these were complicated by lack of information. Because of the poor communications and the wide scatter of small villages and hamlets, little was known of the people living in the basin, and some were so well hidden that they had never paid tax or been counted in censuses. As a result, the Volta compensation and resettlement operation had to begin by looking for the people and finding out more about them.

In the early $1960 s$, once it was definitely known that the dam was to be built, the Ghana government was faced with the immediate and intimidating tasks of identifying, compensating and resettling the people who were to be displaced by the lake. Before independence in 1957, the proposals for resettlement had been similar to those for the Kariba dam: self-help resettlement by the people themselves, with limited government assistance and without any major economic change. Later, this policy was transformed into proposals similar to the Aswan resettlement programmes, for the provision of houses, the collection of communities into larger units, and the establishment of a higher standard of living through modern and mechanised agriculture. This introduction describes the original proposals, the precedents, pressures and delays which came to bear on them, and the new policy which emerged. In the papers which follow, some of the main actors describe the experience and lessons up to March 1965 of many of the activities-organisation, valuation, social survey, social welfare, planning, house design, land clearing, road building, house construction, evacuation, town administration and agricultural development among others-which they carried out in order to implement the programme. Finally, the events from March 1965 to mid-1968 are summarised, and some further practical issues discussed.

\section{The Preparatory Commission Policy: SELF-HELP WITH INGENTIVES}

From the beginning, compensation and resettlement were regarded as closely-related matters and the proper concern and 
responsibility of the government. The consultants who submitted plans for the Volta River Project in I95 I estimated $f_{2}$ million as the cost of compensation and resettlement for the 2,00o square miles which, at that time, it was thought would be flooded. ${ }^{5}$ In its official response in 1952, the government accepted responsibility, stating that it wished 'to assure inhabitants of the areas to be submerged that when the time comes, every person who is displaced or will lose his house, or farms, or any other property will be suitably compensated'. ${ }^{6}$ Of greater significance in its long-term implications was the much publicised and often quoted statement made in 1953 by Kwame Nkrumah, then Prime Minister of the Gold Coast, that, if the project was carried out, the government would ensure that no one was made worse off as a result of the creation of the lake. ${ }^{7}$

In I953, a Preparatory Commission under Commander (now Sir) Robert Jackson began preliminary investigations for the Volta River Project. Although much of the attention of the Commission was directed towards the dam and the smelter, extensive preliminary surveys were undertaken in the flood basin. These included counts of population in almost all the larger villages, surveys of cocoa and oil palms, sample counts of other perennial crops, a valuation of land including its farming potential, and a survey of the public and private buildings that would be inundated. ${ }^{8}$ An impressive amount of data was collected, and, in its Report presented at the end of I955, the Commission was able to recommend a comprehensive set of proposals for compensation and resettlement.

The Commission regarded compensation as a legal obligation and advocated the outright acquisition of valuable rights in the area that would be flooded. ${ }^{9}$ It considered many forms of right, but its most important recommendations were that, in the public sector, roads and public buildings such as schools should be replaced, and, in the private sector, cash compensation should be payable at the current market rates for land, cocoa and other perennial crops, buildings, clay pits and private fishing rights. In addition, 20 per cent of the assessed value of private buildings should be paid to the owners as a 'disturbance element'. Compensation for loss of private rights 
in the area to be inundated was estimated at just over $f^{2}$ million, ${ }^{*}$ and the cost of compensation administration at E700,000.10

Whereas compensation was a legal obligation, resettlement was regarded as a matter of discretion. Three approaches were considered. ${ }^{11}$ The first was for the government to pay what was legally due and to accept no further commitments. The Commission argued that this was unacceptable, since there was a difference between the normal situation of the acquisition of rights to demolish a few houses to make way for a public amenity and the situation in the flood basin where whole communities would be deprived of their villages and of the land from which they obtained their livelihood. The second approach was to evolve a comprehensive policy, set up a central organisation, and re-establish the communities as part of a single major operation. In rejecting this course, which it admitted appeared attractive, the Commission pointed out its disadvantages. With centralised planning, insufficient allowance might be made for local differences in customs, housing and incomes. Further, the spirit of self-help essential for the creation of new communities would almost certainly become one of accepting everything offered, and then of asking for more. ${ }^{12}$ Such a policy would also be very expensive and perhaps impossible entirely to implement. The cost of an official organisation undertaking to replace some 18,000 buildings in scattered localities would be much heavier than if the people concerned built them themselves, using local methods and standards.

The Commission therefore recommended a third policy: resettlement through self-help, guided by incentives. If the inhabitants had to resettle themselves instead of being resettled

* The breakdown of the overall possible commitment for compensation for private rights in the area to be inundated was:

\begin{tabular}{|c|c|}
\hline $\begin{array}{l}\text { Land } \\
\text { Cocoa }\end{array}$ & $\begin{array}{r}\mathcal{E}_{1}, \mathrm{II}_{3}, 680 \\
496,400 \\
210,000\end{array}$ \\
\hline Oil palms and coconut trees & 210,000 \\
\hline $\begin{array}{l}\text { Private buildings } \\
\text { Disturbance element }\end{array}$ & I $75,94^{\circ}$ \\
\hline $\begin{array}{l}\text { Disturbance element } \\
\text { Clay deposits }\end{array}$ & 35,188 \\
\hline $\begin{array}{l}\text { Clay deposits } \\
\text { Fishing rights in creeks }\end{array}$ & 6,000 \\
\hline Fishing rights in creeks & 8,000 \\
\hline Tota & $£ 2,045,208$ \\
\hline
\end{tabular}


$y$ the government, it was thought that communal initiative ould be retained. At the same time, the Commission regnnised that current costs of building were between two and half and three times the assessed market value of buildings, nd suggested: 'A further liability to pay compensation in sspect of housing, calculated at twice the market value ... hould be accepted as a charge on the Project in order to provide fair and equitable treatment.' 13 This sum was not a legal entitlement to householders but would be used as a fund additional to the basic compensation to provide incentives to encourage them to move to the most suitable new localities and to build to a reasonable standard. Indeed, payments from the fund would normally be in the form of housing materials, and those householders who did not wish to build new homes would not be entitled to payments. ${ }^{14}$ In addition, the Commission considered that resettlement would be assisted by the provision of simple village layouts, plans for houses suitable to the resources and habits of the settlers, the loan of blockmaking machines, and free technical advice and training in house construction, as well as the re-establishment of roads and public amenities and an agricultural survey of the areas proposed for resettlement. ${ }^{15}$ The intention was, however, that the people should resettle themselves, refounding their village communities, building their own houses, being subject to the same administration as other communities, and gaining their livelihoods by their own initiative without any radical change of the agricultural system.

In order to appreciate these proposals more fully and to understand the subsequent evolution of resettlement policy, it is important to examine the Commission's recommendations concerning three critical resources: finance, staff, and time.

In the first place, the Preparatory Commission proposed that the cost of the compensation and resettlement exercise should be held down to $£ 4$ million, of which $£ 3.5$ million would be charged to the Volta River Project, and $f_{0} .5$ million charged to the Gold Coast government. ${ }^{16}$ An attempt was made to avoid unspecified liabilities or financial commitments that might become inflated with time. For instance, recognising that the government might in some places have to intervene in 
order to obtain land suitable for resettlement, the Commission proposed that any payments for such land should be met not by the programme direct but by deduction from the compensation for flooded land. ${ }^{17}$ Similarly, evacuation was not envisaged as an expensive, centrally-controlled operation, but as a matter for the initiative of individuals, who could make use of the element of their compensation that was for disturbance. But despite its care to avoid commitments that might slide into heavier expenditure, the Commission left ajar the door that had been opened by the pledge that the government would ensure that no one was made worse off by the creation of the lake. For the Commission concluded its recommendations by saying: 'The programme outlined . . . is designed to meet the needs of the situation, but it does not, of course, exclude additional measures by the Gold Coast Government, either specially devised for the inundated area, or adopted as part of general Gold Coast policy.' 18 The significant point was that, if there were such additional expenditure, it would be the government, and not the Volta River Project, which would have to meet it.*

Secondly, the Commission outlined the staffing implications of its proposals. For the main tasks connected with compensation-demarcating the edge of the lake, determining and assessing private rights, dealing with valuation disputes, paying compensation and auditing-it was estimated that 28 senior staff would have to be recruited and would work for periods

\footnotetext{
* The breakdown of the total estimated cost of compensation and resettlement was:
}

Replacement of public amenities

Compensation for the loss of private rights

Administration (compensation)

Total, compensation

Resettlement: additional commitment

for private housing

Resettlement: other measures

Administration (resettlement)

Total, resettlement

Grand Total

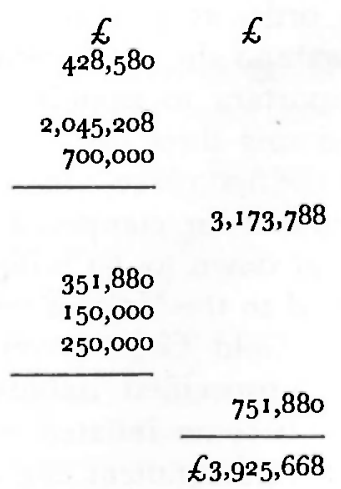

$£ 3,925,668$ 
totalling $62.5 \mathrm{man} /$ years. ${ }^{19}$ The personnel requirements for resettlement would be less, including to senior staff who would work for four years, making a total of 40 man/years. ${ }^{20} \mathrm{In}$ addition, for both compensation and resettlement, many junior staff were considered necessary. For the two operations, personnel emoluments and running expenses together were put at $£ 57^{8}, 5$ oo for compensation and $£$ i80,ooo for resettlement. ${ }^{21}$

In the third place, the Commission estimated the time required for the implementation of its proposals and also outlined a sequence and phasing of activities. Compensation assessment and payment were to precede resettlement so that, when the people moved, they would have resources to assist them, and so that the entitlements of those who accepted the incentives of limited assistance would be known. Before compensation could be paid, it would be necessary to demarcate some 2,200 miles of the lake boundary, to establish land and other property rights within that boundary, to enumerate and value those properties and then to deal with any disputes arising. ${ }^{22}$ In the view of the Commission, a target of appreciably less than three years for the completion of these activities would have been unrealistic. For the compensation and resettlement operations as a whole, four years were considered necessary, before the start of the year in which the lake began to fill. Four years was not, however, the entire period required. There would be limited activities required for three years after resettlement, and, more significantly for any analysis of subsequent policy, other measures were advocated before the four-year period began. These were further surveys - of rights in the flood basin, of land rights, and of the availability of suitable agricultural land in the areas suggested for resettlement. In the view of the Commission, thus, the policy of compensation first and resettlement second required a period of more than four years before the year in which the lake began to fill. ${ }^{23}$

\section{Pregedents, Pressures and Delays, i 956-62}

The Preparatory Commission's Report was submitted at the end of 1955 , and the following five years were dominated by the problems and uncertainties of obtaining finance for the dam 
and smelter. During this period, little attention was paid to compensation and resettlement, and no further surveys were carried out. Experience with resettlement was, however, being gained in two schemes elsewhere in Ghana. Both schemes proved difficult. The first, at Damongo in the Northern Region, was intended to resettle Frafra people from their eroded land, but was partially frustrated by their reluctance to leave their homes and by the hostility of the receiving community. Government assistance was provided in the form of free transport to the settlement area, paid employment from the time of arrival until the planting season, 12 acres of land for each settler, loan of oxen and other incentives, but only limited success was achieved. With the second scheme, the resettlement of the fishing village of Tema to make way for the new port, the problems were more intractable and the experience gained more widely perceived. Although it was proposed as early as r 953 to acquire the land on which the old village of Tema was situated and to resettle the population, it was not until the end of 1959 that the operation was concluded. The government built a new village with a higher standard of housing and provided replacement housing on a room for room basis; but, in spite of this, there was deep and at times violent opposition to the move, deriving partly from political divisions within the community, partly from attitudes to graves, fetishes and magico-religious traditions, and partly from inappropriate initial consultation with the people. The move was eventually achieved without bloodshed through a combination of patient social welfare work, political opportunism, provision of a high standard of replacement housing, and the ultimate sanction of the bulldozer, which demolished the old houses. (The Frafra and Tema schemes are described in greater detail below, on pages $\left.105^{-8 .}\right)^{24}$

The precedents and experience of these two schemes affected Volta resettlement policy. Resettlement came to be seen as politically difficult, and a combination of official permissiveness and substantial inducements appeared necessary for success. Moreover, the association of the Tema operation with the building of a modern port, and the relative lack of financial constraints in planning and carrying it out, established urban 
standards and an urban style as the norm for resettlement in Ghana. Since the Tema evacuees were able to continue fishing after the move, the livelihood of the people after resettlement did not attract as much attention as it might otherwise have done. Another result of the Tema operation was an enhanced standing for the Department of Social Welfare and Community Development in resettlement matters, since a major part of the degree of success achieved could be attributed to it. But most important, perhaps, was the effect of the Frafra, and even more of the Tema, schemes on official perceptions of the problems to be faced with the much larger and widely dispersed Volta resettlement and on assessments of the feasibility of the Preparatory Commission's proposals. For self-help resettlement with incentives, as tried in the Frafra scheme, had not been very successful, whereas the more generous provision of housing and amenities at Tema was felt to have made evacuation less difficult than it would otherwise have been.

At first, the Preparatory Commission's proposals were taken as a basis for policy, but implementation soon ran into problems. It had been recommended that a single organisation should be created to handle compensation and resettlement matters, but this proved difficult. Following progress in the financial negotiations, a Volta River Project (VRP) secretariat was set up towards the end of 1959, and, in 1960, the Administrative Officer who had been in charge at Tema was appointed to the secretariat to take charge of Volta compensation and resettlement matters. But a full organisation within the VRP secretariat could not be formed because of the reluctance of departments to surrender their personnel, a reluctance accentuated by general staff shortages. Only two departmental officers were made fully available to the secretariat: in May I96 I a Principal Agricultural Officer was seconded; and in January 1962 the Social Welfare Officer who had worked at Tema was released for full-time work on Volta resettlement matters. Other departments maintained more direct control over their staff, which made co-ordination over timing and priorities difficult (see below, page $3^{8}$ ), but which had the potential advantage of access to departmental resources. The VRP secretariat was, however, placed in a position of having to bargain and persuade 
departments rather than of being able to exercise direct control. Thus, it was not easy to maintain momentum and to ensure that preliminary activities-such as demarcating the flood boundary and valuing the properties within it, operations requiring particular care and precision and therefore not easily carried out quickly - went forward with the urgency required.

Against these difficulties, the resettlement programme had the advantage of sharing the high political priority of the Volta River Project as a whole. President Nkrumah, then at the zenith of his rule, had identified himself closely with the project and had taken personal responsibility for it. This meant that, without actually having to invoke the President, the secretariat nevertheless enjoyed a high status which enhanced its position in negotiating for services from government departments. Moreover, implicit in the priority of the programme was an opportunity for legitimate access to resources. This strengthened the hand of the secretariat, as government departments saw a chance to participate in a politically acceptable and therefore potentially well-endowed programme; but, at the same time, these attitudes were liable to bring considerable pressure to raise the costs of resettlement. At several large meetings of representatives of government departments called by the VRP secretariat during 196r, VRP staff pointed out the financial implications of any change in policy and tried to hold costs down to the estimated $£ 4$ million. But departmental officers were not so directly responsible for the expenditure that might be incurred, so that for some, among them planners, architects, social welfare workers and agriculturalists, resettlement could appear as more of a creative opportunity than the usual programme restricted by a more limited departmental budget.

In other ways, too, the human and political environment of Ghana under Nkrumah influenced the evolution of resettlement policies. The Volta River Authority (VRA)* was exceptional among para-statal organisations in establishing and retaining an honest and effective administration, protected by a degree

* The Volta River Authority, which succeeded the Volta River Project secretariat, was set up in December 1961 under the Volta River Development Act, $1.96 \mathrm{t}$ (Act 46 , Government Printer, Accra 1961). 
of insulation from the political interference, corruption and inefficiency which were common elsewhere; but, at the same time, the staff of the VRP secretariat and later of the VRA were in the limelight, and politically exposed, by virtue of the very priority and prestige of their work. Nowhere was this more so than in the Resettlement Organisation, responsible as it was for the politically sensitive and potentially explosive operation of moving 80 ,ooo people from their homes and resettling them within an inexorable timetable. Any major disaster or powerful criticism would be laid at the door of the resettlement staff. Moreover, the style of Nkrumah's government was generous and modern, if profligate, and civil servants were aware that not only they but also Ghana would be judged by the operation which they were planning. In addition, it was felt that the people in the flood basin were losing their lands and homes for the sake of Ghana as a whole, and that therefore it was only right that special social welfare measures should be taken for their benefit. In all these circumstances, the rather cautious proposals of the Preparatory Commission, tenable perhaps for a colonial government, appeared inappropriate in independent Ghana, where people and politicians expected something better than simple resettlement by self-help with incentives.

This background strengthened the hands of those departmental officers who favoured more extensive measures than those originally proposed. Town planners and architects combined professional and patriotic enthusiasm in suggesting that the communities should be resettled in modern model villages of which the nation could be proud. Physical planners were able to argue for a more positive approach to resettlement. One plan put it that:

A tour round the entire periphery of the lake carries one from the environment of the twentieth century which may be seen at Akosombo back through the environments of the nineteenth and eighteenth centuries. The eastern and southern fringes are progressing; the northern and western areas are just waiting. In these poor traditional areas, cash compensation would push back the mud and thatched villages, the hand-hoe, malnourishment, disease and poverty 
-push them back but a few miles further into the savannah. Nor would cash compensation advance the economy of the eastern and southern fringes as some thirty thousand settlers simply wedged into the present farms and villages and simply increased density. Cash compensation would not harness the great energy of this manpower or the land or water. ${ }^{25}$

To take advantage of the opportunity they saw in resettlement, some town planners and architects advocated a much more comprehensive policy than the mere provision of technical advice, some building materials and simple village layouts. They recommended instead the introduction of minimum building standards, including landcrete* walls and corrugated aluminium roofs in place of the mud and thatch of traditional houses. They brought vision to policy discussions, and the vision was primarily urban, based less on rural life than on the experience of towns and of town planning.

To the Social Welfare Department, too, the resettlement operation presented a challenge and an opportunity. Self-help was an important tenet of community development. Moreover the performance of the department in the resettlement of Tema made it seem sensible that it should also play a major part in the Volta operation. It also had a Field Technical Unit which could assist in house construction. Like the planners and architects, Social Welfare staff favoured better housing and taking advantage of resettlement to raise the standards of living of the people.

Agriculturalists also saw the resettlement operation as an opportunity. The Ministry of Agriculture needed to put forward proposals to fulfil its targets in the Seven-Year Development Plan, and previous projects had often been unsuccessful. A resettling population could, it was thought, be persuaded to make a radical change from traditional to modern farming methods more easily than one already entrenched on the land. At the same time, surveys were showing that there was less agricultural land available for the resettling communities than had been believed, and that it would be inadequate to sustain them by the traditional system of extensive shifting cultivation.

* A weak ( $1: 12$ to $1: 16$ ) mix of cement and mud. 
Proposals for more intensive, mechanised agriculture with co-operative provision of services and marketing were therefore put forward and were grafted on to resettlement. The agricultural programme was to be financed by the Ministry of Agriculture, and, by promising higher incomes for the people, it could be seen to justify and support the minimum building standards favoured by the architects, planners and social welfare staff.

Throughout the meetings of I $96 \mathrm{I}$, the VRP secretariat tried to reconcile the financial limits set by the Preparatory Commission with the proposals put forward by departments. But, little by little, additional commitments were accepted: that a subsistence allowance might be paid to the people while they were working on their houses; that their labour might be supplemented by the Workers' Brigade if necessary; that the Builders' Brigade might be employed to clear sites for the new settlements; that some minimum building standard should be adopted. Vigorous discussion took place between those responsible for financial control, who considered that the policy that no one should be worse off meant that they should be only marginally better off, and those who saw resettlement as an opportunity to create new communities with a substantially higher standard of living and technology.

The various factors outlined above-the precedents and experience of earlier resettlement operations, the political environment, departmental pressures-might not of themselves have forced a radical reappraisal of policy. But, in the event, shortage of time became a decisive and irresistible constraint which narrowed the options open and made a new policy inevitable. By the end of 1961 , dam construction was already under way and the lake was expected to begin to form in mid-1964, leaving less than three years before the inhabitants of the basin would start to be flooded out. Surveys had, it is true, been begun, but these had themselves added to the problems. Demarcation of the flood boundary had proceeded slowly in adverse conditions and had fallen far behind schedule, making more difficult the tasks of valuation and social survey. Site selection for resettlement was emerging as a knotty issue, complicated by survey findings that many sites provisionally 
recommended by the Preparatory Commission were either on poor soils or already extensively farmed. It was even uncertain how many people were living in the lake area. The Preparatory Commission had put it at $62,500,{ }^{26}$ but on the basis of the census of 1960 a figure of 50,000 was quoted during $196 \mathrm{I}$, and 20,00o was even mentioned.

At the end of $196 \mathrm{I}$, matters were aggravated by the transfer of the officer in charge of resettlement. Precious time was lost during the first five months of 1962 while an unsuccessful attempt was made to recruit a retired expatriate to replace him. When, in May I962, a senior member of VRA staff was appointed Resettlement Officer, little more than two years remained before the flood, as against the period of over four years considered necessary by the Preparatory Commission. Given the uncertain information available, the wide scatter of communities, the poor communications in the lake basin, the emerging problems of site selection, the shortages of staff, and above all the inexorable deadline for dam-completion, it was difficult to see how resettlement could be carried out at all without human disaster. Ghana faced what amounted to a national emergency. The time factor alone ruled out any possibility of following the Preparatory Commission's proposal for payment of compensation before resettlement. The Resettlement Officer and those committed to the operation faced a daunting and complex challenge. The crisis demanded a new policy followed by urgent action, but in mid-I 962 that new policy had yet to be worked out.

Formulating a New Policy, i 96i-63

One of the first acts of the Resettlement Officer was to form a Working Party of key officers (for a description of this Working Party, see below, pages $36-9$ ). Although the vRA Board, chaired by President Nkrumah, was the ultimate authority, and the Chief Executive of the vRA included resettlement matters among his many responsibilities, it was this Working Party, meeting fortnightly, which became the main centre of policy discussions. The Resettlement Officer, as chairman, wrote the minutes and circulated them widely to principal secretaries, 
departmental heads and district commissioners. From these minutes, it is possible to trace how in 1962 and 1963 a new policy was devised to meet the crisis. For the purposes of analysis and description, three interwoven threads can be separated out: first, housing and self-help; second, the size of the resettlements; and third, compensation.

The first thread concerns housing and self-help. The Preparatory Commission had recommended that 'the Gold Coast Government should not accept any responsibility for any actual construction' ${ }^{27}$ and had proposed that, through a community spirit of self-help and selective incentives, the people should be encouraged to build 'new dwellings of adequate though modest standards ${ }^{\mathbf{2 8}}$ for themselves. It was not a long step from this position to the minimum housing standards put forward in the meetings of $196 \mathrm{r}$, but still at that stage regarded as optional. However, when the minimum housing standards were costed, they were found to require over $£^{6}$ million, over half as much again as the total budget.

The proposals for minimum housing standards placed the Department of Social Welfare in a dilemma: it favoured selfhelp, communal effort and improved standards of living, but the planners and architects argued that the houses required could not be built in the time by self-help and that contractors and direct labour would have to be used. For a time, the Department of Social Welfare assumed that communal labour coupled with technical assistance from its Field Technical Unit would be adequate. The department supported the adoption of different housing types to fit the traditions and needs of the different communities affected, particularly in the north where it was expected that many people would want to continue to live in round huts surrounding a compound. This suggestion was, however, attacked by a government minister from the north who insisted that northerners should not be fobbed off with what he feared might be second-best housing, but should receive exactly the same treatment as people in the south. Meanwhile, experience at the first resettlement site, Nkwakubew, suggested that communal labour was difficult to organise and slow in achievement, and that a high-powered centralised organisation would be needed if sufficient housing was to be 
built before the lake filled. Such an organisation, working against tight deadlines, would itself be driven to favour uniformity in construction, in order to simplify its tasks of supply and building. Faced with these political and practical pressures for standardisation, and appreciating the scale and urgency of the challenge, the Department of Social Welfare came to accept that its original proposals could not be sustained; direct labour would have to be used and uniform housing designs adopted.

Attempts were made, however, to retain some self-help. At one small site, Todome, where the inhabitants of the lower half of a village on a steep slope were resettling nearby, new homes were eventually completed by self-help, but only after a prolonged effort and with considerable strain on the resources of the regional organisation of the Department of Social Welfare and Community Development, which had responsibility for organising the self-help programme. Elsewhere, it was intended that communal labour should be used for the construction of streets, street drains, schools, community centres, post offices and markets. In practice, however, communal labour was difficult to mobilise and even more difficult to sustain. At Kete Krachi, it was only after a special visit by a minister that some clearing could be started; and the work stopped almost immediately with the onset of Ramadan, when the Muslims pointed out that they could scarcely carry out heavy work while fasting all day. The main attempt to retain some self-help was, however, through an ingenious innovation - the core or nuclear house which was to be built on the resettlement sites. Direct labour was to be used to construct a landcrete house with a corrugated aluminium roof and cement floor large enough for two rooms and two verandahs, but the walls of only one room were to be completed, leaving the remaining walls to be added on later by the settler and his family. Every family which opted for official resettlement was to have a core house and would thus be provided with immediate shelter; a higher standard of housing would be achieved; and the principle of self-help would not be abandoned, only postponed in its application.

The second thread of policy concerned who should be 
resettled and the size of resettlement units. The Preparatory Commission thought in terms of re-founding village communities, but foresaw one town (Kete Krachi) and fifty villages of between 200 and 1,200 inhabitants. Of the estimated 62,500 people in the lake basin at the end of 1954, it was thought that only 40,000 lived there permanently, with another 10,000 having dwellings in the area but also homes in other parts of the country, and about 12,500 being 'strangers', most notably Tongu fishermen and Konkomba farmers, in temporary residence. The Tongu fishermen would not be eligible for compensation for land ownership or perennial crops, since they had neither, and it was thought that strangers might not always wish to build new villages but might instead prefer to return to their home towns or move to other parts of the country. In addition, the Krobo farmers in South Afram who traditionally lived on individual homesteads were expected to resettle themselves in a similar pattern not entailing nucleated villages. Consequently, it was anticipated that a considerable proportion of the population would not move to resettlement villages. ${ }^{29}$

In the event, however, several factors combined to increase the numbers of people for whom the official resettlement operation had to cater. The population to be displaced, thought to have been 62,500 at the end of 1954 , was found to be some 80,000 in 1963 . There were political pressures on the Resettlement Office to include in the programme all the inhabitants of the flood basin: two Tongu leaders who were government ministers made it known that they expected the Tongu fishermen to be given new houses and to receive the same treatment as other people. The agriculturalists were anxious that the Krobo farmers should be included wherever possible, since, being energetic and able farmers, they would increase the chances of success for the agricultural programme. Administratively, too, in the time and with the staff resources available, to have excluded any group of persons from valuation, social survey and resettlement would have been difficult and open to abuses. All the inhabitants of the flood area were therefore included, and all were given the choice of either accepting minimum compensation and resettling themselves or being resettled in one of the official sites. Many who at first 
opted to resettle themselves later changed their minds. A substantial proportion of the Tongu fishermen altered their decisions in favour of official resettlement, after heavy floods in I 963 (unconnected with the dam) convinced them that the bigger flood prophesied by the government really would occur. The Social Welfare workers who enumerated, consulted and exhorted the people also persuaded many to accept official resettlement, being themselves assured that it would bring the benefits of modern facilities, better housing, and higher incomes through improved agriculture. Resettlement became a crusade for social and economic development, and in the end only some I 3 per cent of the population decided to resettle themselves.

At the same time as the numbers for whom it was realised resettlement would have to be organised were increasing, the question of the size and number of settlements had to be decided. The planners began by thinking in terms of a wide range of sizes of settlement, from a central town with a population of at least 5,000 down to clusters of individual farmsteads. In the interests of improved services, some amalgamations of smaller villages were suggested, since communities below a certain size could not economically support amenities like primary and middle schools, an electricity supply or a neighbourhood centre. In the Volta Basin Area Development Plan, the argument was carried further in favour of modernisation of human settlement from 'the hundreds of small subsistence villages along the water's edge to larger and fewer townships with regional markets and industries' ${ }^{30}$ As discussions continued through 1962 and into 1963 this change of emphasis was reflected in the disappearance of 'village' from resettlement vocabulary, and, after a brief interval when 'sites' were talked of, its replacement by 'town'. But more than the drive for urban services and modernity, it was the sheer pressure of time and the administrative load that forced the adoption of a more standardised policy. Site negotiations were complex and difficult, requiring several types of survey and much consultation among and between both departmental officers and local groups. It became vital that the number of such operations should be limited, and this implied fewer and therefore larger resettlements. This had other advantages besides saving time 
and administration. The agriculturalists were by no means opposed to larger settlements since they would provide a compact and more easily controlled labour force for their proposed mechanised agriculture with co-operative services. Later too, with the construction programme, there were powerful arguments for achieving economies of scale through fewer, larger, towns. Divided though they were on some other issues, all departments were agreed on the convenience of grouping into larger residential units, and the Department of Social Welfare worked to persuade communities to join together as a necessary condition for the higher standards of living that were anticipated. The outcome was $5^{2}$ resettlement sites with an average planned population of over 1,300 persons each.

The third policy thread was compensation. As we have seen, the Preparatory Commission had proposed that compensation should precede resettlement. Compensation for land and perennial crops was to be in cash, and for buildings either in cash at their current market value or in building materials at three times their current market value, in conjunction with the resettlement programme. However, assessment of compensation emerged as an increasingly complex undertaking as, in equity, more and more individual variations were considered. At one time, differing rates of compensation for land of differing potential were even contemplated. But to be able to compensate for land in any detailed way, a full survey would have had to be carried out before the lake formed, and this was utterly beyond the resources of the Survey Department, already fully extended on demarcating the lake boundary. What was attempted had to be trimmed to what could be achieved. Thus, the valuation teams which started work in May 196 I enumerated rooms, buildings and perennial crops, but made no attempt to value land. Even so, the valuations and details of buildings were not ready in time to be used in the planning of the resettlement towns, so that the Tema system of house replacement on a room for room basis, proposed for Volta in I96I, would have been administratively out of the question, even if it had been physically and financially feasible. Indeed, in the short time available and with the concentration of attention on the more 
critical questions of evacuation and resettlement, the only course of action open was to obtain as much information as possible before the flood, and then assess and pay compensation later, unavoidably reversing the order of activities recommended by the Preparatory Commission.

For compensation to be fair, effective and not too delayed, some drastic simplifications were required. Administratively, it was fortunate that the Volta River Development Act provided that 'compensation may be paid in money or in non-monetary assistance towards settlement or both. No person shall be entitled to dispute the compensation offered to him by reason only that it is not in money, whether in whole or in part.' ${ }^{31}$ The cost of construction of a core house was likely to be greater than the vast majority of compensation entitlements, making it possible to blot them out by treating housing as compensation. This, then, became the last thread that tied up resettlement policy in its new package. Because house construction by selfhelp had to be abandoned and construction by direct labour accepted, and because the people were being strongly encouraged to accept official resettlement rather than take cash compensation and resettle themselves, it seemed that the innumerable variations and details of compensation could in most cases be smothered and eliminated in the one standardised act of presenting each family with a core house.

Largely because of the construction costs, this new policy could be implemented only if more funds were made available. The ceiling for resettlement and compensation expenditure was raised from the original $\mathcal{E}_{4}$ million to $\AA^{8.5}$ million, not including the agricultural programme which was separately financed. Fortunately, there were savings on the main dam project which could be diverted to resettlement to meet this additional cost. By the end of 1964 , resettlement expenditure of $£ 7.7$ million had been brought to book, of which $\mathcal{E}^{6 \cdot 0}$ million had been on clearing and construction.

The implementation of the new resettlement policy up until March 1965 is described in the papers which follow. It is unnecessary to anticipate the story here. But, since the scale of what was done is sometimes concealed by the modesty of the papers, it is right to emphasise that, by the end of 1964 , 
nearly 2,00o miles of the lake boundary had been demarcated, nearly 15,000 buildings referenced, a comprehensive social survey of some 80,000 people executed, over 14,000 acres of land cleared, over 500 miles of laterite road constructed or improved, 52 settlement sites negotiated and planned, over I I, ooo core houses built, and over ro, ooo families out of an estimated I5,000 safely evacuated. All this, it must be remembered, was achieved without any serious opposition to evacuation, without (so far as is known) any loss of life, often in remote country with poor communications, difficult terrain and thick forest, and under extreme pressure from shortage of time. By any standards, the central activities performed up to that point were successful, in some respects outstandingly so. What these activities were, how they were carried out, the difficulties encountered and the lessons learnt from the experience are the subject of the papers which follow, and which were presented at the Volta Resettlement Symposium held in Kumasi in March 1965 .

\section{REFERENCES}

I. See John A. King, Jr., Economic Development Projects and Their Appraisal, Cases and Principles from the Experience of the World Bank, Johns Hopkins Press, Baltimore I967, pp. 128-55; and R. J. Moxon, Volta: Man's Greatest Lake, Deutsch, London I969. See also the Bibliography.

2. Reported in David Brokensha, ed., "Volta Resettlement, Ethnographic Notes on Some of the Southern Areas", mimeo, Department of Sociology, University of Ghana, Legon, April 1962, p. 38 .

3. For more detailed discussion of the economic level of the population before resettlement, see Rowena M. Lawson, "An Interim Economic Appraisal of the Volta Resettlement Scheme", The Nigerian Journal of Economic and Social Studies, Vol. x, No. I, March I968, pp. 95-109, especially pp. 96-8.

4. For more detailed descriptions, see Brokensha, op. cit., especially pp. 37 et seq.; and Rowena M. Lawson, "The Structure, Migration and Resettlement of Ewe Fishing Units", African Studies, Vol. xvII, No. I, I958, pp. 2 I-7. 
5. Development of the Volta River Basin, a Statement by the Government of the Gold Coast on the Volta River Project and Related Matters, Government Printing Department, Accra 1952, p. 6. The consultants were Sir William Halcrow and Partners.

6. Ibid., p. 6.

7. Quoted in The Volta River Project, Vol. I: Report of the Preparatory Commission (henceforth referred to as VRP I), HMSO, London I 956 , p. 45 .

8. See ibid., p. 45, for a fuller list of the surveys carried out. The survey findings of the Preparatory Commission and its recommendations for compensation and resettlement are to be found summarised on pp. 45-54, and in greater detail in The Volta River Project, Vol. II: Appendices to the Report of the Preparatory Commission (henceforth referred to as VRP II), HMso, London 1956, Appendix vi, pp. 65-I35, "Effects of the Project in the Area Subject to Inundation".

9. Compensation matters are covered in VRP II, pp. II6-23. A wide range of rights affected and a learned discussion of compensation matters in relation to Ghana law may be found in E. A. K. Akuoko, "Legal Rights in Resettlement Properties", in "Volta Resettlement Symposium Papers", papers read at the Volta Resettlement Symposium held at Kumasi, March 23-7, 1965, mimeo, Volta River Authority, Accra, and Faculty of Architecture, University of Science and Technology, Kumasi, 1965, pp. 1 $57-65$.

I0. VRP II, pp. I20-3.

11. See ibid, pp. I23-4, for a fuller presentation of the three alternatives, their advantages and disadvantages.

I2. Ibid., p. I 24 .

I3. VRP I, p. 49. Private buildings were valued at $\mathcal{E}_{175,940}$; the additional fund was to total $£ 35^{\mathrm{I}, 880}$.

I4. Ibid., p. 52, and VRP II, p. I33.

I5. Ibid., p. I34.

I6. Ibid., p. I35.

I 7. Ibid., p. I 29.

I8. Ibid., p. I35.

19. Ibid., pp. 122-3.

20. Ibid., p. 132 .

21. Ibid., pp. 123 and 132 .

22. Ibid., p. $12 \mathrm{I}$.

23. Ibid., pp. I $3^{I-2}$, for estimates of the time required.

24. For the Tema scheme, see also G. W. Amarteifio, D. A. P. 


\section{INTRODUCTION}

Butcher and David Whitham, Tema Manhean, a Study of Resettlement, Planning Research Studies Number Three, published for the University of Science and Technology, Kumasi, by Ghana Universities Press, Accra 1966.

25. "Volta Lake Basin Area Development Plan", mimeo, undated but probably I $96 \mathrm{I}, \mathrm{p}$. Io.

26. VRP II, p. 7 I.

27. Ibid., p. 126.

28. Ibid., p. I 33 .

29. For this paragraph, see ibid., pp. 80, I25-6, and I3o.

30. "Volta Lake Basin Area Development Plan", op. cit., p. I2.

31. Volta River Development Act, Ig6r, section 28(b). 


\section{2}

\section{Postscript and Discussion \\ ROBERT CHAMBERS}

\section{Postscript: The Resettlement Programme, 1965-68}

APART FROM the Introduction, the papers in this book are substantially those presented at the Volta Resettlement Symposium in March i 965 . They were written while the experience of surveys, site selection, planning, construction and evacuation was still vivid. The high point of crisis during the evacuations of 1964 had been effectively tackled and a satisfaction at the achievement was thoroughly justified. Despite the desperate shortage of time (aggravated by closure of the dam ahead of schedule), bad communications, the scattered population and the multiple difficulties of building new towns, the main tasks had been successfully completed. Evacuation had been carried out with a high degree of co-operation from the people. Permanent shelter had been provided for them. Roads, schools and water supplies had been constructed in order to enable them to achieve a higher standard of welfare. Food from the World Food Program (WFP) was being supplied to the people who had been resettled for the first six months until they could grow their own food. An outside observer could not fail to be impressed by the dedication and skill of those who had implemented the programme, and by its achievements and successes.

These papers were not written with the benefit of hindsight derived from the three years that were to follow, yet already they foresaw most of the main problems that were to arise. The history of resettled communities is almost always a catalogue of problems and responses to them, and in this the Volta resettlement towns have been no exception. From 1965 to 1968 they were beset with difficulties, but these do not amount to

Note: References for this chapter will be found on pages $268-9$. 
the whole story. The account that follows seeks to describe the events and changes in the resettlement programme in a way which does justice to the actors and the obstacles which they faced, and which may suggest the relevance of the experience for other similar programmes. The description can, for convenience, be grouped under three headings: first, social welfare and the resettlement towns, including compensation and housing, all areas in which Social Welfare staff were involved; second, agriculture, land and the World Food Program (WFP); and third, the settlers' experience and reactions.

\section{Sogial Welfare and the Resettlement Towns}

The Social Welfare staff who had carried out the social survey and evacuation stayed on to administer the resettlements. While working for the VRA, the senior Community Development Assistant (CDA) in each settlement was, after 1964 , designated Town Manager and paid a higher salary than before in recognition of his increased responsibilities. He was usually assisted and complemented by a female CDA and, in the larger settlements, a second male CDA. At the end of 1965 , when the VRA intended to withdraw from financial and administrative responsibility for the towns, the Town Managers and GDAS were transferred to the Department of Social Welfare, and the Town Managers lost their higher salaries and reverted to the normal cDA scale of remuneration. They were, however, still expected to constitute a government presence in the settlements, to control housing development, to ensure the maintenance of facilities such as water supplies, markets and sanitation, to organise refuse collection and dumping, to launch and support Town Development Committees, and to act in a general co-ordinating role with agricultural and health staff, water pump attendants and teachers.

At first, the CDAs were helped by the standing they had earned during the earlier stages of the operation. It was they who had warned the people that the flood would come, who had paid special attention to the people's wishes in the negotiations for the new sites, and who had brought the people to the new towns, allocated the new houses, and issued the WFP food. 
But after resettlement some of their shortcomings began to tell. Many of them were young and not widely-experienced men who did not find it easy to handle the pressing problems and the lonely and responsible administrative tasks with which they were faced. They felt isolated, and in most cases were far from Accra, with which their contacts were typically through occasional visits of staff and a slow postal system. From time to time their future and even their salary payments appeared uncertain, which further undermined their confidence. From I 965 to 1968 they remained in the towns, while their roles and authority gradually diminished, shifting from comprehensive responsibility for welfare to what was closer to a combination of normal social welfare functions and the administration of a government housing estate.

The Resettlement Office and the Social Welfare staff were presented with many awkward and untidy problems, all of them smaller and less urgent than those created by the rising lake in 1964 , but all demanding decision and action. As the lake continued to rise, though more and more slowly, evacuation of the remaining communities had to be carried out. Water supplies were inadequate in some settlements, either because boreholes were brackish or because surface water supplies were only seasonal. Some remote settlements had access roads which were difficult to maintain or which were flooded or in danger of being flooded by the lake. Then there were occasional settlements with too few houses, and others with too many, though considering the hectic circumstances in which planning had had to be carried out, the fit between supply and demand was commendably close.

Many of the problems which arose concerned compensation. The separate data from the valuation survey and the social survey were cross-checked, and a reconciliation team was put on to the task of investigating discrepancies, thus providing a safeguard against any possible errors in assessment. The records of the two surveys proved useful in handling the numerous claims received alleging that property had not been valued, had been valued incorrectly, had been attributed to the wrong owner, and so forth. A number of claims arose from allegations that the boundary of the lake had been inaccurately 
surveyed, but on investigation these proved unfounded. The process leading to the payment of compensation was lengthy. Assessment was carried out by the Lands Department and payment by a special section of the Resettlement Office. Most compensation entitlements for those who accepted the new houses were covered by the estimated average value of new cedis (NG) 700* for the core house and NGi,200 for the completed house together with other amenities which were subsequently charged; but, in spite of this, by mid-rg68 much compensation had still to be paid out. Of the estimated total of $\mathrm{NG} \cdot 5$ million for inundated crops and buildings that was to be disbursed in addition to the core house element in compensation, less than NGo. 6 million had been paid out by the end of 1967 . Claimants impatient for their compensation made the journey to Accra to try and obtain payment. However, these difficulties were tackled in 1968 through the setting up of a team to move round the settlements and make payments on the spot.

Many of the problems involving Social Welfare staff and settlers concerned housing. The settlers realised that they had been provided with a high standard of housing, and many were particularly pleased to have keys so that for the first time they could lock up their homes. But they also experienced and complained about inconveniences. They found the new houses hotter during the day and colder at night than their traditional mud and thatch homes (see graph, page I 74). When they made a wood fire on the cooking verandah of the $P$ and $R$ type houses, the smoke was a nuisance. The honeycombs, designed to allow free circulation of air, also let in water when it rained and dust when the wind blew. As has already been mentioned (page I89), a number of roofs blew off in the storms of February I965; this made such a deep impression that even in 1968 some people left the settlements affected whenever a high wind blew. By far the strongest complaint was, however, about the inadequacy of the single room provided. It resulted in overcrowding, and polygamous men found it embarrassing to have more than one wife in the same room-they had either to split their families or to put up with considerable inconvenience.

* The cedi was created with the value 2.4 cedis $=f(\mathrm{G})$ I. After Ghana's devaluation in 1967,2 new cedis (NC 2) were equivalent to the former $f(G) \mathbf{r}$. 
Many of these shortcomings had been recognised and anticipated by the planners, architects and policy-makers who, constrained by limited resources, had tried to provide the best they could in the circumstances. In addition, after resettlement, official efforts were made to improve the housing. After some of the roofs had blown off, the attachments of roofs to house frames were strengthened. More important for the satisfaction of settlers, a crash house-completion programme was mounted and planned to help settlers complete the core houses up to two rooms and two porches. The settlers were provided with cement, sand and block-making machines and, under the supervision of Social Welfare staff, made the landcrete blocks that were required. A skilled team circulated among the settlements and, with some unskilled assistance from the settlers, began to complete the houses. However, the programme was not easy to administer, since continuing financial allocations had to be negotiated, import licences for cement obtained and cement supplied to the settlements in a sequence that would fit in with the movements of the mobile team. Moreover, settler absenteeism sometimes made it difficult to ensure that blocks were ready on time, that cement, once delivered, did not deteriorate, or that all the houses in a settlement town could be finished during the visit of the team. Retarded by difficulties such as these, the programme was still continuing in 1968.

In the meantime, the Resettlement Office and the Town Managers faced a major dilemma over housing standards and controls. The settlers wanted to make themselves at home by building what came to be known as 'unauthorised structures'. In some towns settlers put up baths, kitchens, hen coops, livestock enclosures and extra rooms not according to the architects' plans, often using materials salvaged from their old houses. A report in August 1964 on New Ajena highlighted the issue. It argued that a solution had to be found to the problems of unauthorised structures 'in order to save these modern, beautifully planned and designed model townships from degenerating into disorganised old fashioned settlements or slums'. ${ }^{1}$ There was a considerable debate between those who favoured strict controls, as embodied in draft model bye-laws, and those who favoured a more laissez-faire approach. A hand- 
book proposed for Town Managers was delayed as a result of divergent opinions about the degree of control that should be exercised over building, and an intention to provide nine planning assistants, one to each of the administrative areas, fell through because of difficulties of recruitment and training. Town Managers varied in their handling of these testing problems. Most of them, aware that they might be judged by the tidiness of their towns, tried to prevent or at least limit the building of shacks and other 'unplanned' structures. Some ordered the demolition of those that had been put up. The result was sometimes a bare and barrack-like appearance.* Generally, however, Town Managers gave way to the wishes of settlers in $\mathrm{P}$ and $\mathrm{R}$ type houses (which did not include baths) and allowed them to use thatch and materials salvaged from their previous homes to build traditional open-air enclosures for washing. In addition, settlers were commonly not prevented from the practice, which became widespread, of blocking the honeycombs on the houses with cement. It was in the most urban settlements-Kete Krachi and Yeji-that the most variation in building occurred, in the latter case giving the impression that the settlers had been able to build freely to their own satisfaction. Until I 968 the desire of settlers to extend their houses using mud and thatch was contained, in the hope that additional building could maintain the standard and style of the core house. In r 968 , however, it was recognised that extension in landcrete was beyond the means of the vast majority of settlers and instructions were issued that they could build on to their houses in mud, providing the roof was of corrugated iron and the layout followed a simple plan.

One of the tasks of Town Managers was to form Town Development Committees. There was a wide variety of systems of representation and election, with either the District Commissioner, Town Manager or chief, or some combination of these three, deciding procedure, and members being either appointed, or elected in public meeting, or co-opted from the

* Bareness was most noticeable in the north-west, where goats ate hedges and tree seedlings. A programme was mounted to plant trees and hedges, but had to be abandoned because of cost. Nevertheless, settlers did on their own plant substantial numbers of shade trees. 
Town Development Committees of the old communities. A traditional leader was sometimes made the president. As elsewhere in Ghana, the chairman was often the Convention People's Party (CPP) chairman, or a chief or headman, while the secretary was usually either the Town Manager or the GPP secretary. The Committees were meant to organise and supervise sanitation and cleanliness through communal labour, to cooperate with the local authority particularly over tax collection, and to provide a focal point for the discussion of local problems. They were, in fact, meant to take over some of the Town Managers' functions. Since they were predominantly political bodies with their members drawn mainly from the GPP, it is not surprising that, after the coup of February 1966 and the disbandment and public discrediting of the CPP, most of them lapsed and were not immediately replaced. Social Welfare staff had originally been influential in seeing that the Committees met, but by 1968 they no longer automatically attended meetings, which were anyway less regular than before.

At the end of 1965 , the vRA attempted to withdraw from financial and administrative commitments to the resettlements. Social Welfare staff were transferred to the Department of Social Welfare. The heavy equipment that was being used to clear land for agriculture was sold off. Road maintenance was handed over to the Ghana National Construction Corporation. Sanitary and water services were devolved to local authorities. At the same time, settlers paid half and then, later, full local authority rates. However, difficulties were experienced in handing over responsibility for services-as they have been with many other settlement schemes-with the VRA as the parent agency anxious that standards should be maintained, and the receiving authority sometimes lacking the financial allocations or staff necessary and anyway resenting the costs of providing higher standards of service for the settlers than for other communities. Nevertheless, from the beginning of 1966 pump attendants and conservancy staff were employed by local authorities and sanitation and water supplies ceased to be such a direct concern of the Social Welfare staff, although they were expected to intervene where a service was badly neglected. Meanwhile, the Resettlement Officer and the vRA retained 
oversight of the settlement towns and continued to co-ordinate work and act as a clearing house for problems, besides handling the records of the settlements, compensation claims and payments and administrative aspects of the house-completion programme.

In the settlement towns, with the ending of the wFP food issues, the decline of Town Development Committees, the handing over of maintenance responsibilities for services and the slowing pace of house completion, the intended functions of the cDAs shifted towards more usual social welfare roles such as adult education, care of the blind and the imparting of domestic skills to the women. They were also expected to continue to try to help the various communities to adjust to one another. But, with time, the main attention of the resettlement programme moved from welfare to economy. For, as several of the contributors of symposium papers pointed out, it was the agricultural programme on which the ultimate viability of the settlements depended.

\section{Agrigulture, LANd ANd the World Food PROGRAM}

The programme for intensive agriculture based on the resettlement towns was adopted for several reasons. It was expected to make it possible for the settlers to achieve a higher standard of living. Since the land available at the resettlement sites was too small to allow settlers to continue extensive shifting cultivation, a more intensive system seemed essential. The Ministry of Agriculture was also enthusiastic about the possibilities of mechanised agriculture with farmer co-operatives for the supply of inputs and for marketing. The vRA readily accepted the programme, since it was to be financed by the Ministry of Agriculture and since it promised a level of incomes which would improve the lot of the people and enable the resettlement towns to become economically viable as communities. Agriculture was, indeed, the essential foundation for the long-term success of many of the social aspects of the resettlement programme.

From the beginning, the agricultural programme was beset 
with difficulties. At first, by far the most damaging was the way in which it fell behind schedule. Clearing forest and bush was seriously delayed. In 1962 a directive from the cabinet ordered that the supervision and use of all heavy equipment should be transferred from the Ministry of Agriculture to the United Ghana Farmers' Co-operative Council (UGFGC), a largely political body with very limited agricultural or administrative competence. Despite repeated requests from the VRA for machinery and promises from the UGFGC that it would be supplied, none ever materialised. When the VRA was eventually forced to order its own machinery, valuable time had been lost. On top of this, obtaining import licences, negotiating suppliers' credits and ordering through the government supply commission further delayed the programme. When priority was necessarily given to clearing for roads and town sites to enable construction to go ahead, agricultural clearing was even further held up. By the end of 1964 , instead of the hoped for 54,000 acres, only some 8,000 acres had been cleared for agriculture. By the end of 1965 , to be sure, this figure had risen to I 5,000 acres, but at that time the VRA, anxious to avoid further expenditure, sold off the heavy clearing equipment and clearing virtually ceased. ${ }^{2}$

Even if adequate land had been cleared, mechanical cultivation would not have been possible immediately on the great majority of sites. Some tractors ordered in February 1963 did not arrive until October 1965 . In addition, staff training was a major task which took time. This was undertaken on a planned and phased basis, but it was only after some of the 400 Massey Ferguson tractors and ancillary equipment ${ }^{3}$ had arrived that the training of tractor operators could begin. There was a shortage of agricultural staff experienced with mechanisation, and some were sent abroad for training as part of the equipment purchase arrangements. It was only gradually that Agricultural Assistants, usually young men with ten years' education and three years' subsequent agricultural training, were posted to the settlements to take responsibility for the tractor fleets, the growing agricultural staff and the cultivation programme.

To have stood a reasonable chance of inducting the settlers into the entirely new agricultural system, it would have been 
an advantage to have had ready on their arrival cleared land, mechanical equipment and adequately trained staff. Only rarely were any of these conditions met. Most settlers arrived to find that, instead of the higher standard of living they had been promised, there was not even any cleared land for them to cultivate. They were, it is true, well provided with food from the WFP and with instructions on how to prepare and eat it, but with few exceptions the agricultural programme failed to provide them with the intended independent means of subsistence. Some continued to cultivate their old lands where these had not yet been flooded. Others negotiated with local landowners and, usually for the payment of a fee, obtained cultivation rights and continued their traditional shifting agriculture. Yet others obtained casual jobs in the surrounding areas. A few lucky settlers were very heavily subsidised in pig and poultry production at three settlements (Mpakadan, Nkwakubew, Todome) and obtained substantial incomes for as long as the livestock schemes were maintained. A few, too, were able to cultivate tobacco, and some of these received sums which encouraged them to continue. However, a majority of settlers did not benefit from the official agricultural programme, and some, particularly Tongu fishermen and Krobo farmers, while accepting resettlement houses, maintained their livelihoods elsewhere by adapting their previous economic systems to the new situation.

When the tractors had arrived and the operators had been trained, other factors compounded the difficulties of introducing the proposed system of co-operatives and mechanisation for arable farming. For farmers in Ghana the word 'co-operative' had come to be associated with the UGFCC, which was virtually a wing of the CPP, and with exploitation of farmers by petty party officials. ${ }^{4}$ On the Volta resettlements farmers regarded co-operative organisation not as voluntary but as a scheme imposed by authority and inferior to their traditional practices. In any case, junior agricultural staff did not have a very clear idea of co-operative organisation, and few co-operatives were in fact launched. Where they were, they were not necessarily pioneering ventures on the part of settlers: at Senchi, for instance, the formation of a settlement sugar co-operative was in hand only after neighbouring farmers had already started 
one; while in Yeji an Agricultural Assistant had to use some of the more enterprising host farmers to persuade the more conservative settlers to join in the creation of a rice co-operative. By mid-I 968 , no co-operative had been registered, though a few were in the process of becoming registered.

Many other obstacles impeded settler participation in mechanised farming. Fearing reliance on one mechanised crop, settlers gave priority to their separate food crop production. Absenteeism made the co-ordination of mechanisation difficult. Settlers sometimes neglected to perform a vital activity, such as curing tobacco, forcing the agricultural staff to choose between carrying it out by direct labour or losing the crop. Maize, groundnuts, tobacco, cassava and rice were the crops recorded as most commonly grown, but even in I 967 yields were not officially known, the reason given being that the settlers were secretive and harvested when agricultural staff were not present. Until I968, tractor services were provided entirely free, but when charges were introduced most of those settlers who had previously accepted mechanisation opted out. One result was that in some places, despite a shortage of cultivable land, the areas cleared and previously mechanised were no longer cultivated and began to revert to bush. The agricultural staff were left doing very little.

As so often with mechanised cultivation schemes operated by governments, weaknesses appeared in the control of tractor operation, in maintenance and in the supply of spare parts. With the Volta agricultural programme these problems were exacerbated by the dispersal of the settlements and difficult communications. Although there had often been little work for the tractors, by mid-I 968 about one third were unserviceable. The records kept did not permit any per hour or per acre costings and there seemed no good reason to disbelieve the view that it had been common for tractors to be used for private purposes, whether agricultural or recreational. Although there had been no economic evaluation of the mechanical cultivation programme, it would have been difficult to argue that economically it had been anything but a disaster up to that time (but see page $\mathbf{2 4 5}$ for a discussion of the extent to which an economic evaluation is appropriate). 
Economically, the livestock programmes fared no better. Pig rearing was introduced at Mpakadan and Nkwakubew, and broiler fowls at Nkwakubew and Todome. A bold start was made to these schemes. In the last quarter of 1964 , the stock of sows and gilts was 520, roo hogs were marketed, and no less than 100,000 broiler chicks were received by air from Holland. But soon both pigs and broilers ran into trouble. From 1964 onwards there were losses from diseases, but the most serious problem was the rapid rise in the price of local feed. Severe cuts of imports in 1964-66 resulted in much greater demand for local foodstuffs, and the price of maize, which was part of the feed for the livestock schemes, rose to twice and sometimes even four times the pre-1 964 price. The hope that mechanised cultivation in the settlements would produce the necessary basic food ingredient was not realised because of the delays and inadequacies of that programme. In these circumstances the livestock schemes were uneconomic. The poultry scheme at Todome ceased to receive chicks in October 1965. The schemes at Mpakadan and Nkwakubew continued but in a heavily-subsidised form, with supply of young livestock, supervision of husbandry, veterinary services and marketing all provided by the Ministry of Agriculture, and with the settlers' activities limited to feeding the animals and collecting the returns from sale after the deduction of some costs. In mid-ı 968 there did not seem any immediate chance of either the pig or the poultry scheme becoming viable in any normal economic sense.

In I966, the already almost insuperable difficulties of the agricultural programme were yet further aggravated by loss of access to land. Under the Nkrumah regime, protest was imprudent and landholders had acquiesced in the claims to their land made by and on behalf of the resettling communities. But after the military coup of February I 966 and the establishment of a National Liberation Council, a freer atmosphere prevailed, and they felt able to assert their rights, sometimes using force to drive settlers off the land they had begun to cultivate. This was not serious in the north, the north-west or the Afram Plains, where there was plenty of land, usually within the jurisdiction of the settlers' own chief so that access was 
easy. It was in the more densely-populated and cultivated south and south-east that the problem was acute. The National Liberation Council agreed that the land must be acquired legally and the slow and cumbersome procedures necessary began to be set in motion. But the surveyors, whose work was considered necessary before land could be gazetted for acquisition, were often themselves chased off by the owners, with the result that in 1968 senior agricultural staff were busily committed to the essentially political tasks of explanation and pacification to obtain agreement for the surveys, and agricultural development was even further delayed.

In 1966 , as it came to be recognised that the mechanised programme could not provide a livelihood for most of the settlers in the foreseeable future, a more modest objective of clearing a subsistence plot for each settler family was considered. Towards this end an application was made to the World Food Program (WFP) in April I 966 for food aid to feed settlers while they hand-cleared land for subsequent food cultivation. This was discussed by the Tenth Session of the Intergovernmental Committee of the WFP in October 1966, as a result of which a four-man mission, headed by Professor Wilbrandt of Gottingen University, visited Ghana for three weeks in February and March 1967 in order to appraise the request and make recommendations. Following the Report of the Wilbrandt mission, a further modified request was sent to the WFP in June, and a plan of operation between the Ghana government and the WFP was finally signed in December 1967 .

The intention of the programme, designated WFP 356 , was to make it possible for settler and host farmer male adults over the age of seventeen to hand-clear subsistence plots of between two and four acres each. Some 35,000 men were to clear a total of approximately 105,000 acres. While working, they would be remunerated in food provided by the WFP and in cash by the Ghana government at not less than half the prevailing wage rates. Over a period of three years and three months, the WFP was to supply food aid to the value of $\$$ (us) 3.3 million.* For its part, the Ghana government, through the VRA as its executing agency, was to provide an estimated $\$$ (Us) $2 \cdot 8$ million to cover,

* Figures have been rounded to the nearest $\$($ Us)o. I million. 


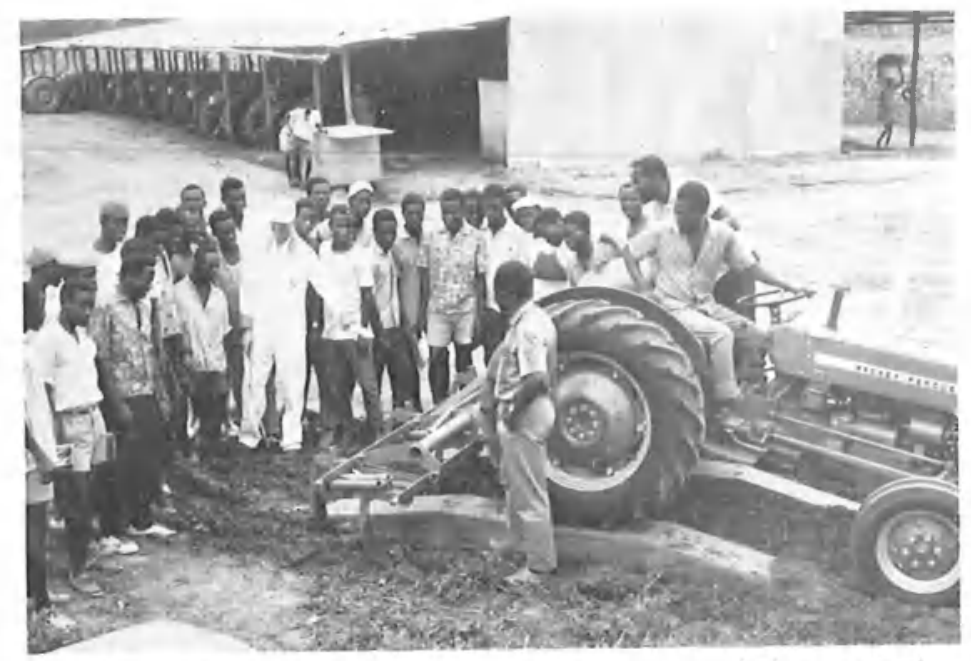

27. The agricultural programme. Tractor drivers being trained as part of the agreement for the purchase of foo tractors and ancillary equipment.

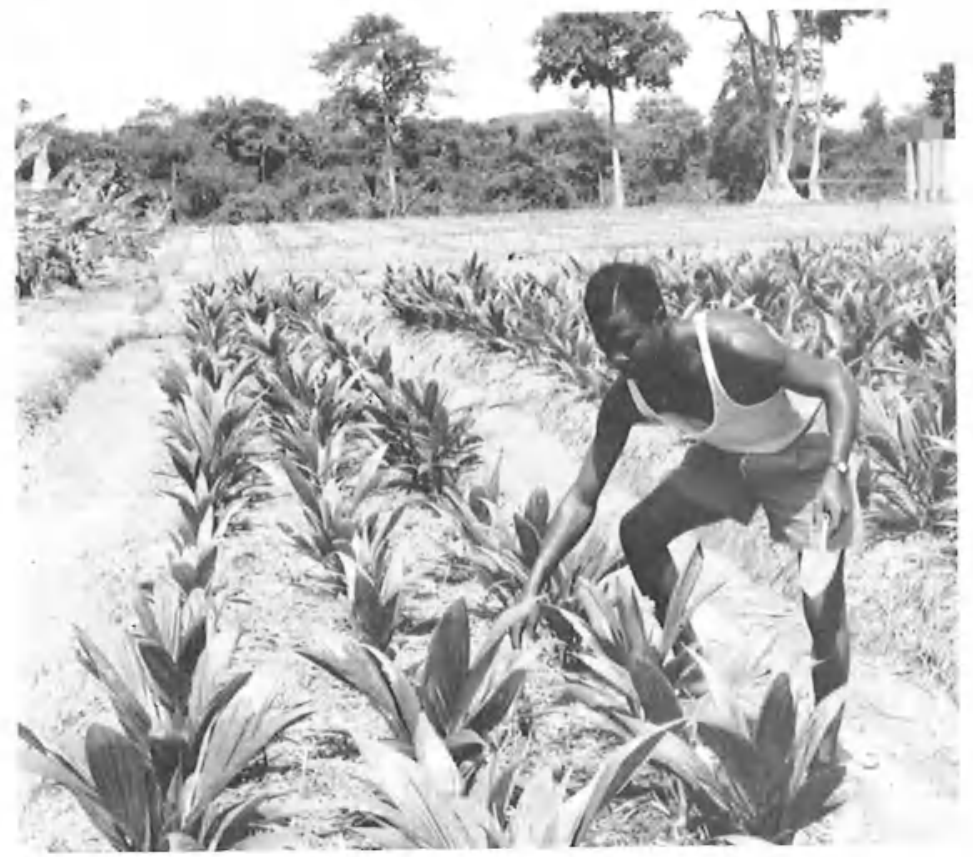

28. Tending tobacco plants. 


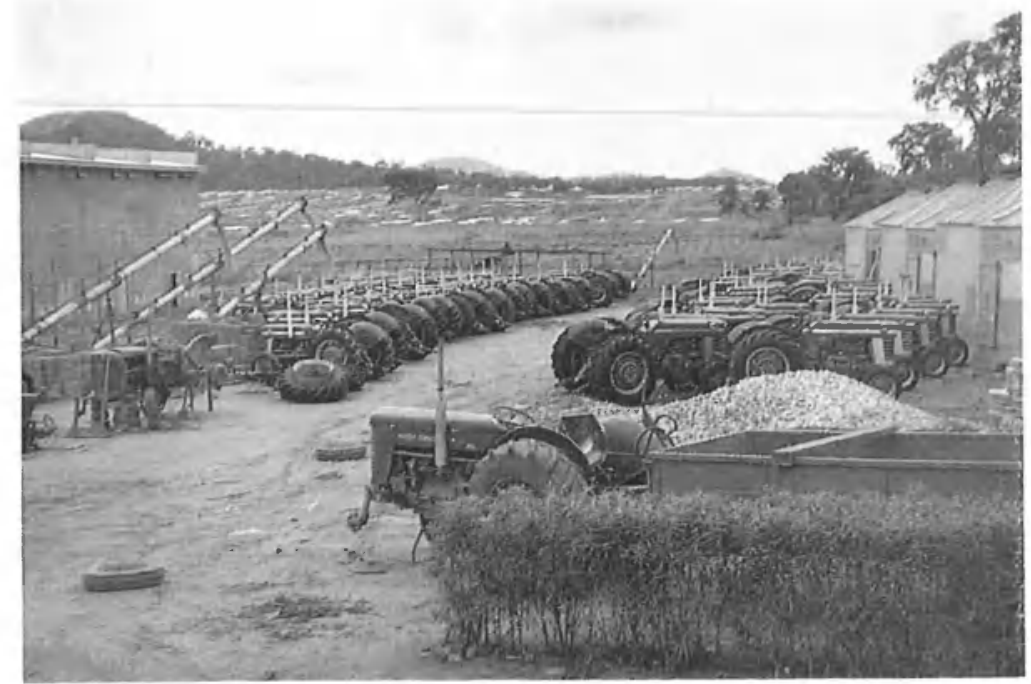

29. Tractors standing at Mpakadan. (The failure of the programme of mechanised agriculture is discussed on pages 233-40.)

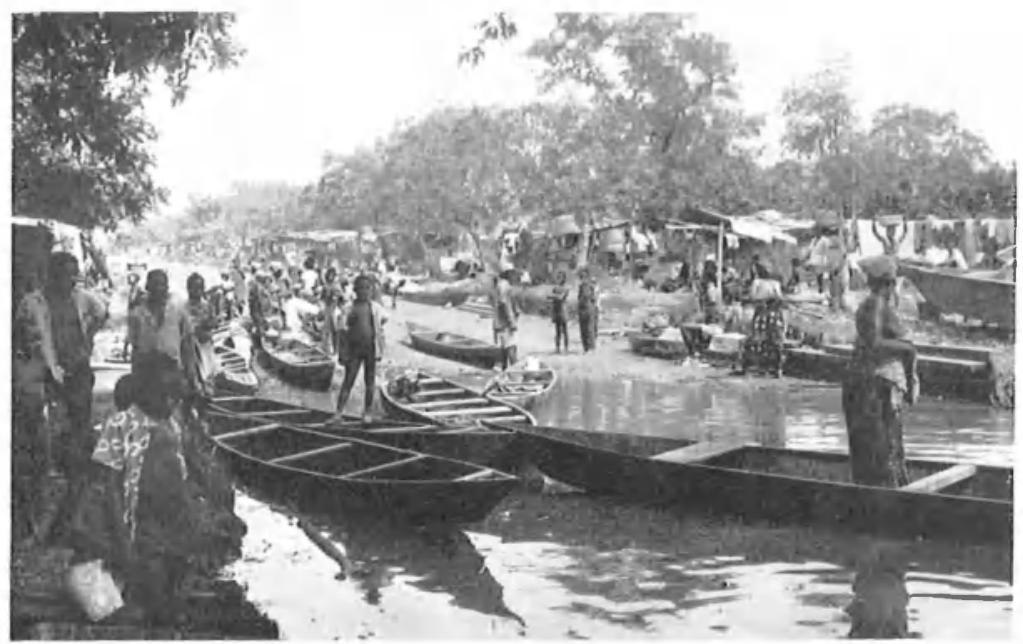

3o. Spontaneous settlement by Tongu fishermen in ${ }_{9} 6_{5}$ at the point wherc the main road to Kete Krachi had been cut by the lake. Many fishermen accepted resettlement houses but continued to migrate, exploiting the rapidly multiplying fish population of the lake, and selling their catches to traders from Accra, Kumasi and elsewhere. 
among other costs, handling and distributing the food, paying the cash wages and obtaining hand tools.

Much thought and effort went into working out and adapting the programme and the agreement. The WFP stipulated that, before the programme began, the land to be cleared must first be legally acquired. The VRA's agricultural staff worked out systems for the administration of the programme and for land tenure. The government was to acquire the land outright and then issue renewable 33-year leases to the settlers and host farmers who took part and who would thus become tenants. Draft rules provided for the payment of peppercorn rents, inheritance without subdivisions and ejection for persistent refusal to apply recommended husbandry practices. Although the plots were to be for subsistence food crops, agricultural staff were to maintain some surveillance of cultivation. A socio-economic survey of the settlements, recommended by the Wilbrandt mission, was started in October $1967 .^{*}$ As a result of recommendations stemming from this research, the cash component was later removed from WFP 356 . The project agreement was altered so that food was to be given as an incentive or reward for work done on a voluntary basis. Instead of being issued with food and wages on a daily basis, settlers were to be allocated their plots which they were to clear themselves, rations being given to them according to the number of man/days required to clear an area by traditional methods. In addition, in order that settlers should have some capital for farming, the compensation policy was altered. Instead of offsetting the value of flooded houses and crops against the value of the new houses, cash was to be paid for crops flooded and the new house was to be considered as a replacement for the one flooded.

In conjunction with the moves towards implementation of WFP 356, the Resettlement Agricultural Unit was, in November 1967, transferred from the Ministry of Agriculture to the VRA. At the same time, the VRA accepted accounting responsibility

* The survey, with settlement cDAs as enumerators, was directed by D. A. P. Butcher as part of the Volta Lake Research Project of the United Nations Development Program Special Fund and the Food and Agriculture Organisation of the United Nations. 
for the programme, and a very senior Ghanaian agriculturalist, formerly Principal Secretary to the Ministry of Agriculture, was appointed to head the organisation. Reforms were quickly introduced. Eighty of the idle tractors and operators were transferred to the Ministry of Agriculture. Charges for tractor services were for the first time announced. A determined attempt was made to press ahead with acquiring land. But the difficulties were such that, by mid-I 968 , there was no immediate prospect of WFP 356 being able to proceed on any scale. Meanwhile, the large bureaucracy of the Agricultural Unit (numbering I,33 I staff at the end of 1967 ) was largely immobile, usually lacking settler participation where there was land and lacking land where there might have been settler participation. Nor did the agricultural staff on the settlements appear to be exercising many striking initiatives to overcome these constraints. The legacies of earlier difficulties and demoralisation made retrenchment and rehabilitation of the programme a daunting challenge which would require exceptional administration, some good luck and very substantial resources to overcome.

\section{Settlers' Experience and Reactions}

As was recognised in the social survey and in resettlement planning, the processes of evacuation, resettlement and forming new, larger communities were bound to involve stress. The care taken to consult villages about resettlement sites and about other villages with which they would like to join, to keep the old communities physically intact in the new towns, and to give people houses near to their preferred neighbours, must all have reduced the shock of the change. In addition, shelter and food were assured, and Social Welfare staff tried in many ways to ease the transition for the evacuees. But resettlement involved elements which although intended to be for the benefit of the people were, at least in the short run, bound to have an unsettling effect. The uncertainty about relationships with the other groups in the new town and with the hosts; the inconvenience of the single room of the core house; the unfamiliar separateness and spacing of the houses; the newness of the arrangements for sanitation, schooling for children and 
water supply; the strangeness of the food; and most of all the lack of means of independent subsistence through traditional agriculture-all these could hardly fail to add to the disturbance of losing a familiar environment and livelihood.

Bringing small communities together into larger units was recognised as likely to create conflicts. Without the earlier patient negotiation over grouping and site selection, these conflicts could have been much more acute. As it was, problems of allegiance and precedence between chiefs and headmen in the new towns were often difficult to resolve. The tension between the two chiefs at Mpam (New Mpamu) described by Martha Dodoo (page 20I) continued unabated into I968, and for a year and a half prevented the installation of a postal agency in the settlement because of a dispute between the two communities over its siting. Elsewhere conflict within resettlement towns was not often as intense; but, in the absence of sociological studies in depth, it is impossible to say with any certainty to what extent the separate communities had integrated. One possible indicator of social cohesion was the number of gong-gong beaters (town criers). Each headman of a village normally had one gong-gong beater who made public announcements, and many of these continued in the new settlements. In Danyigba in 1965 there were said to be eight gong-gong beaters, but in 1968 only five, suggesting, by this measure at least, that some integration might have taken place in the interval.

As within a resettlement town, so between the inhabitants of the town and the host communities, there were various relationships and tensions. As would be expected, where the settlers and the host community were of the same ethnic group and owed allegiance to the same chief, integration and co-operation were relatively close. Where a small town or village was partly flooded and resettlement was a leapfrog operation (Yeji, Kete Krachi, Todome), politico-ethnic problems were also relatively slight, and previous forms of organisation could persist, with a joint Town Development Committee and joint communal labour. Where a resettlement was grafted on to an existing village, a joint Town Development Committee was sometimes formed and joint activities 
undertaken, but it was more common for formal organisation to be separate. Where some facilities were shared, a common pattern was that some non-settler children would attend the new settlement school, but that settlers would go to the old town market. Where the new settlements were isolated, political relationships tended to centre on questions of land. In the South Afram, where land was scarce, disputes were intense and bitter, and the settlements appeared as foreign intrusions which the unwilling hosts tried to contain. On the Afram Plains and in parts of the north and north-west where land was plentiful, the hosts' attitudes were more generous and there was less difficulty over access and use. Along the east bank of the lake where the resettlements had been implanted in areas that were already occupied, the situation was more complex and variable. In most places, some negotiations by the settlers were necessary before they could cultivate subsistence plots.

From an early stage, absenteeism was a feature of many settlement towns. In some cases, families decamped as a whole; in others, wives or a wife were left behind with children who continued their education in the settlement school while the husband farmed, fished or worked elsewhere. It would be misleading to interpret all this absenteeism as an indication of failure, since migration, sometimes leaving behind an empty house, is a common practice in Ghana and does not necessarily imply abandonment. Moreover, there are many combinations of reasons why people leave settlement schemes, and simple generalisations are almost certain to have limited application. All the same, two main clusters of reasons were probably the most powerful inducements to leave.

In the first place, settlers were subject to unfamiliar constraints associated with housing administration. Settlers needed more rooms, but the house-completion programme encountered financial, administrative and supply problems which slowed it down, and completion, anyway, left the household with only two rooms and two porches. To obtain permission to extend beyond that size was difficult, as various plans and application forms had to be submitted to Accra; in any case, extension was virtually impossible for most settlers, since landcrete blocks were expensive and difficult to make and the cement required 
was often unobtainable. Settlers wanted to build in traditional materials-mud and thatch-for virtually no cost except labour, but CDAs were cautious in interpreting the regulations; in the rare cases where a formal application was made, they were inclined to pass it up to higher authority. It was easier to refer upwards in the hierarchy and in the meantime to prevent extensions than to accept responsibility for allowing them. Nor were settlers permitted to sell or rent their houses, although it was the long-term intention that they should be allowed to do so. In the short term, thus, it was not easy for them to acquire a secure sense of ownership and of having struck roots in the new towns. Indeed, some gave the impression that they felt they were camping on government property rather than permanently living in the houses. In these circumstances, temporary or permanent migration can be interpreted as, on one level, a search for a less restricted environment. The position was changed in 1968 , however, when it was decided to allow extensions to houses in mud and corrugated iron, but the full effect of this new policy would take some time to become evident.

A second, and probably more decisive, set of reasons for absenteeism was the lack of secure livelihood to be obtained near the settlement towns and the relatively good opportunities elsewhere. Almost invariably, one of two adverse situations prevailed: either settlers were short of land, or their participation in the mechanised agricultural programme was unsatisfactory and unpredictable. In 1966 and 1967 , in the south and east, settlers and officials were often driven off the land, so that tractors and agricultural staff stood idle and cleared land began to revert to bush. But where, in the north, north-west and the Afram Plains, access to land was not a problem, settlers were able to continue traditional cultivation and were hesitant about taking part in the mechanised programme. As with similar schemes elsewhere in Africa, their caution was probably rational, based upon a perception of high risks and uncertain rewards. Settlers could have many fears: that the tractors might stop working or be transferred; that mechanical cultivation might be untimely; that an unfamiliar cash crop might fail or be attacked by disease; that the junior official in charge might act in a discriminatory fashion or seek personal 
advantage through his control of resources; that it might prove impossible to handle the labour peaks of weeding or harvesting or that these might conflict with the higher priority of food crops; that the uncertain charges to be levied for services would be high or hard to pay; that land tenure and even ownership of the crop were insecure; and that there would probably be long delays between harvesting and payout. Granted that some at least of these fears were justified, it is not surprising that most of those settlers who had a chance to take part in the mechanised programme in 1968 decided to abstain.

In contrast, the economic opportunities outside the settlements were often better. The fish population of the new lake multiplied several-fold, feeding on the flooded vegetation, and many of the Tongu fishermen, having collected their keys, left the settlements in order to exploit this rich opportunity. Other Tongu from outside the lake basin migrated to join them on the lakeshore. New temporary, and later more permanent, settlements sprang up where old roads cut by the lake gave good communications to the markets of Accra, Kumasi and elsewhere. By 1968 , sited as they were on the edge of the lake, the Tongu had also begun to tap the potential of market gardening irrigation on the land seasonally exposed by the draw-down of the lake. Many Krobo farmers, too, left the settlements, sometimes as at Somanya after first planting their town plots with cassava right up to the doors of their houses. As before, they formed companies to buy land and continued their traditional farming system. In the Pawmpawm area, however, they saw the possibilities of the lake and took to fishing. Other settlers migrated in search of farmland, particularly from the eastern shore of the lake across to the Afram Plains, and from the settlements north of Kete Krachi across the Oti arm of the lake to land near the new north-south trunk road which gave access to the markets of the south (see map, page 5o). It can be expected that the settlers who moved out of the towns were the younger and more energetic, while those who remained were the older and more indigent. Such a conclusion is supported by the dependent attitudes of many of those who remained and who, whenever they encountered an official, were more inclined to beg the government for further free 
assistance to make up for their real or exaggerated sufferings than to think in terms of working to help themselves.

\section{Mid-i 968 : Taking Stock}

Evaluation of resettlement programmes is complicated by three factors in particular. In the first place, there are typically multiple objectives and activities in a programme, with a corresponding number of criteria against which success or failure can be judged. In the case of the Volta programme, the purposes up to 1968 had been as diverse as identifying the population in the lake basin, constructing resettlement towns, moving the people peacefully, creating new communities with higher standards of amenity and income and integrating these into their new environments. Different aims dominated different stages of the operation, and the objectives were achieved to different degrees in the various resettlement areas. To select one aim, such as agricultural viability, and to proclaim the programme a failure up to 1968 would be as distorting as to select another, such as peaceful evacuation, and to proclaim the programme a remarkable success, true though both these judgments appear on their own.

Second, there are many unknowns in assessing costs and benefits. For example, a high cost in financial terms or in the use of administrative resources may be more apparent than real if more beneficial alternative uses do not exist; and, in Nkrumah's Ghana, there was such extensive waste and corruption that it may well be asked whether, if the resources devoted to the Volta resettlement agricultural programme had been invested elsewhere-for example, in State Farms-the result might not have been even worse.

Third, evaluations depend upon the time scale adopted. With a programme as complex and varied as the Volta resettlements, it is perhaps always too early to pass judgment. A settlement town that appears nearly abandoned in I 968 may have emerged as a flourishing centre by 1978 ; and, equally, the opposite might occur. Nevertheless, with these qualifications, some of the more obvious costs and benefits as they appeared in mid-r 968 can now be stated. 
An official estimate of financial costs up to June 30,1968 , is given in Table I, below. Agricultural and non-agricultural costs cannot be completely separated, and it must be noted that, among the costs incurred by the VRA as opposed to the Ministry of Agriculture, some were essentially part of the agricultural programme. In terms of orders of magnitude it may not be far from the truth to say that the non-agricultural aspects of resettlement had cost NQ2 I million ( $£$ I0.5 million), * and that the agricultural programme had cost $N G_{5}$ million ( 2.5 million), giving a total of the order of $N \&_{2} 6$ million ( $f$ i 3 million).

\section{TABLE I}

Estimated Costs of the Volta Resettlement Programme to June 30, I $968^{1}$

A. Incurred by VRA

$\begin{array}{cc}\text { Itemised } & \text { Totals } \\ \text { NG } & \text { NG }\end{array}$

Housing (including townsite clearing, construction overheads and equipment)

\section{Schools}

Markets I3,000,000:

Streets

Latrines

Water Supplies

Roads

Farmland Clearing

Compensation for Crops and Buildings

Consulting Engineering

Administration (including demarcation surveys, property valuation, soil surveys, agricultural expenses, costs of evacuation, some wFr local costs, planning and general administration expenses)

$$
\frac{2,765,000^{3}}{21,692,000} \quad 21,692,000
$$$$
\text { Total, vRA }
$$

* Most of the expenditure was incurred in Ghanaian pounds, which have been converted here at the rate of $f(\mathrm{c})_{\mathrm{I}}=\mathrm{N} \ell_{2}$. Conversions to $f$ sterling are complicated by British and Ghanaian devaluations and are here made at the equivalent of par before the devaluations. In May 1969 the rate was $£$ i sterling $=$ N\& 2.45 . 
B. Incurred by Ministry of Agriculture

$\begin{array}{cc}\text { Itemised } & \text { Totals } \\ \text { NG } & \text { NG }\end{array}$

Capital and Development 400 Tractors and Ancillary

Machinery etc.

Land Clearing and Farming

Machinery and Equipment

Broiler Houses

Pig Houses

$2,000,000^{4}$

967,000

I 77,000

13,000

Tobacco Barns

27,000

wFP Local Costs

9,000

I 68,000

' Total Capital and Development

Recurrent

including personal emoluments, travelling and transport, and general expenses

I, I 76,000

Total, Ministry of Agriculture

$3,361,000$

NG

Grand Total

$4,537,000$

$4,537,000$

$26,229,000$

Notes:

I. Source: Communication from the Chief Executive, VRA, dated May I9, 1969 .

2. Construction overheads and equipment were estimated to have cost about N\&6 million out of this total.

3. This does not include assistance from the armed forces in the evacuation of 1964 .

4. The figure for tractors and ancillary machinery is a cruder estimate than the other capital and development figures.

There were also commitments for future expenditure. Estimates were necessarily tentative, but are presented in Table 2, below.

TABLE 2

Estimates of Orders of Magnitude for Expenditure from July I, I968, to December 3 I, 197 I

I. Acquisition of land in the flood basin

NG million

2. Acquisition of 438,000 acres of resettlement land

I $\cdot 0$

3. Compensation for crops and buildings (outstanding)

4. Government contributions to wFP $35^{6}$ 
5. Recurrent expenditure for resettlement and

$N Q$ million agricultural programmes at $\mathrm{NCo} \cdot 5$ million per annum for $3 \frac{i}{2}$ years

6. Cost of completing settlement houses, improving township facilities, and payments for additional compensation

Total $N \mathscr{G}$ million

Notes:

Items 1 to 4 were estimates by the VRA.

Item 5 is the writer's estimate based on vRA figures for previous recurrent expenditure.

Item 6 was put forward subsequent to June 1968 in connection with proposed revisions of policy and was under consideration in May 1969 .

It appeared that if WFP 356 was fully implemented and completed by the end of 1971 as originally planned, and if the VRA's estimates were allocated and expended without any additions, then the resettlement, compensation and agricultural programmes up to the end of 197 I would have cost the VRA and the Ghana government a sum of the order of NQ 34 million, the equivalent of between $f_{1} 6$ million and $f_{17}$ million sterling.*

There is little to be gained by setting this figure against the f4 million ceiling suggested by the Preparatory Commission in 1955. Substantial inflation and the changed objectives of the programme make any comparison difficult and unrewarding. But any such comparison, certainly up to 1965 , does not provide grounds for supposing that expenditure on resettlement and compensation had been excessive. Rather, when the scale of achievement up to that date is taken into account, what seems to require explanation is not the extent of expenditure but its moderation.

Other costs were less easy to assess. If shadow prices were allocated to imports to allow for the scarcity of foreign exchange which affected Ghana during the period under review, costs would be higher (all cement supplies and machinery were

* In view of the imponderables of conversion rates, it would have little meaning to give a more precise figure. 
imported). The resettlement programme had also absorbed scarce trained manpower and administrative capacity which might otherwise have been deployed elsewhere. There were, for instance, two or three cDAs in each settlement, and, by the end of 1967 , sixty-two Agricultural Assistants had been committed to the programme, while in Ghana as a whole the ratio of Agricultural Assistants to farmers in 1966 was said to have been only I to $20,000 .{ }^{5}$ Another cost was the degree of demoralisation and disillusion of both staff and settlers which made it more difficult to retrieve the situation. Yet another aspect of cost was the deep commitment of the VRA and the government to maintaining and rehabilitating the programme.

On the benefit side, some of the more obvious achievements by mid-I 968 could be expressed statistically: the demarcation of nearly 2,000 miles of lake boundary before the lake filled; the reference and valuation of 14,849 buildings, and 46,000 acres of crops; the social survey covering 78,946 people; the clearing for resettlement sites and agriculture of 16,670 acres of forest and bush; the negotiation and planning of 52 sites; the construction of 12,67 I core houses, 8I school blocks containing 404 classrooms, and 46 markets; the installation of 63 water supplies; the construction or improvement of $5^{12}$ miles of laterite road and 95 miles of streets; and the evacuation of I 2,479 families. ${ }^{6}$ In addition, over NGo. 5 million of compensation had been paid out. A Social Welfare presence had been maintained in the settlement towns and had worked on community development, housing administration and the housecompletion programme. A very large number of individual problems raised by people affected by the lake had been investigated and dealt with. ${ }^{7}$ An ambitious agricultural programme had been launched and a large agricultural staff deployed, albeit without proportionate results. There had also been some crop and livestock production, though this had been very heavily subsidised.

To these achievements must be added benefits which may be no less real for being less tangible. Many children found themselves for the first time close to a primary school. It was potentially less difficult than before to provide health services to the people, and lakeside health and vector control were the 
responsibility of a special unit of the VRA. Instruction in health, home economics and other aspects of social welfare had been provided in the settlement towns. In addition, the very disturbance of resettlement, the conflicts of communities, the absenteeism, even the disillusion of settlers with the agricultural programme could have positive as well as negative aspects, and certainly do not lend themselves, given that development is full of twists and turns, to any simple assessment. Another benefit which cannot be quantified was the experience gained by staff who had lived through the resettlement and agricultural operations. The Volta dam and the resettlement programme has also caught the imagination of Ghana and acted as a focus for national aspiration, loyalty and effort. Internationally, too, the operation has attracted attention, and the measures and experience of Volta could influence programmes elsewhere, most immediately that for evacuating and resettling the population to be flooded out by the Kainji dam in Northern Nigeria.

Any stock-taking is inseparable from the problems which existed in mid-I 968 and the proposals for overcoming them. The Resettlement Organisation was faced with an intractable situation, but without the advantages of the inexorable deadline or the sense of national emergency which had obtained in May 1962. As before, the physical dispersal of the population and the slow communications of the basin aggravated the difficulties. But whereas earlier the field staffi had been newly recruited and could be imbued with enthusiasm, now they were dispersed and accustomed to relatively inactive routine. The division of the settlements into five districts, each supervised by an intermediate level of staff-Assistant Community Development Officers in Social Welfare, District Agricultural Officers in the Agricultural Unit-could assist only if the devolution of authority to those levels was supported by an adequate exercise of initiative at them. Moreover, the two parallel hierarchies of Social Welfare and Agriculture inevitably overlapped. It was also not easy, given the bureaucratic imperatives for standardisation, to differentiate policies for the very different conditions of individual settlements, although such differentiation was proposed through wFP 356 . Devolution 
to local authorities of responsibility for sanitation and water supplies had in some cases led to neglect and subsequent intervention by the VRA to maintain services. The settlers also presented problems. Many had migrated, whether temporarily or permanently, and many of those who remained gave an impression of apathy, dependence and suspicion of official agricultural proposals. Perhaps most seriously of all, at least half the resettlements lacked access to adequate land, and no quick legal means of obtaining access was available. Consequently, the agricultural programme, in serious straits anyway, was largely immobilised.

It was against this background that attempts were being made to complete all housing and to obtain adequate land for those resettlements to which it was denied. Proposals were in hand to set up regional and district advisory committees to assist co-ordination and integration at local levels. Planning went ahead for the implementation of WFP 356 , intended to provide food as an incentive to settlers to clear plots of land for their own cultivation. These tasks in aggregate appeared if anything more difficult than the original programme of survey, planning, construction and evacuation. Far from drawing to a close, the Volta resettlement experience showed signs of continuing in an active manner for several years.

\section{Concluding Discussion}

For others faced with similar tasks, much of the value of the Volta resettlement experience will be at the level of particular approaches and measures. Many of these are explicit or implicit in the symposium papers and do not need to be repeated here. On the positive side, some of the most outstanding are the social survey, the humane approach to moving the people, and the way in which the Working Party and specialist staff completed their tasks. But the resettlement operation and its aftermath, besides presenting particular lessons, also raise issues of strategic importance in planning and implementing resettlement and development programmes. Those that can be generalised may be applicable to a wider range of projects than just resettlement schemes. 


\section{Social and Egonomig Poligies}

The style of the Volta resettlement operation was strongly influenced by the permissiveness and understanding of a social welfare approach to development. The peaceful co-operation of the evacuation can be attributed to many factors, including the people's perception of the authority of the government and the inexorable rise of the waters of the lake with which there could be no argument; but a major contribution to its success was the package of measures - the social survey, the discussions about resettlement groupings and sites, the opportunity to choose to be resettled or to accept compensation, the provision for the propitiation of fetishes and graves, the written warnings of the date of evacuation, the care taken to ease the shock of moving, the provision of new houses and better services-which reflected a concern for the welfare of the people and an acceptance of responsibility for their well-being. This approach did not cease with the arrival of the evacuees in the new towns. It continued in the provision of free food for six months, in the house-completion programme, in the maintenance of services and in various smaller ways through the presence and activities of Social Welfare staff in the settlements.

The dominance and persistence of a social welfare approach affected economic aspects of the programme. Attention was focused on the immediate wishes of the people and the measures which would most readily and immediately secure their contentment and co-operation. The sequence of concern moved from gaining acceptance of the move, to evacuation, to provision of shelter and food, to community integration and welfare. In these circumstances, and given the urgency of the operation, longer-term economic considerations received a lower priority. Allowing some groups of people to choose sites which were unsuitable on technical grounds (such as lack of water or lack of agricultural land) achieved a short-term gain in co-operation and satisfaction, but usually a long-term cost in persisting responsibility for settlements without adequate services or resources. Again, compensation in cash had been considered, and was indeed an entitlement of those who opted to resettle themselves; but for the bulk of the settlers it was 
feared that the money might be dissipated irresponsibly. For those who accepted resettlement, most of the compensation for buildings and perennial crops was provided not in capital which could be used productively but in fixed, unproductive assets in the form of housing. Moreover, for as long as special standards of building were required for extending the core houses beyond the two-room two-porch stage, settlers' scarce working capital was liable to be diverted from directly productive use, such as paying seasonal labour or renting land, to buying unproductive cement and corrugated iron. The housing did satisfy the immediate need for shelter, but at the potential cost of future production.

An alternative that might be considered for other programmes is compensation in productive assets, such as boats and nets for fishermen, and tools, seeds and roads for farmers, combined with a simpler form of housing.* In the words of a pre-settlement study for another scheme, made in Ghana in 1966: 'It must be in the wake of an improved economy and changed life that a new demand for a different kind of housing will arise, and not the other way round. The resettlement operation will have been successful if the settlers can meet such a demand from their own resources when it arises.' ${ }^{8}$ With higher incomes, settlers can make their own choices about subsequent investment-whether in housing, schooling, services, consumption or further production. In the long run, it is economic success that makes welfare possible, not the other way round.

On most settlement schemes, an earlier humanitarian or political rationale gives way over time to economic criteria for evaluation. The exceptional persistence of the welfare rationale on the Volta resettlements, justified by the failures in agriculture, has in turn had the effect of protecting the heavily-subsidised and inefficient agricultural programme from economic evaluation. The mechanical cultivation and livestock programmes, indefensible by any normal economic criteria, could be justified and sustained on the grounds that there were obligations to the

* This form of compensation was proposed by the sociologist at the time of the minor Volta floods in 1963 , but by that time there was very little room for manoeuvre in altering policies. 
settlers, and the programmes were not intended to be economic anyway. The very failure of the agricultural programme, and hence the lack of income to the settlers, strengthened the case for a persistence of welfare justifications, which in turn completed the circle by protecting the agricultural programme.

A central dilemma of the Volta programme, as with other centrally-organised resettlement operations, is the effect of official action on settler attitudes. Once government has touched people, they are never quite the same again. As with other welfare-oriented settlement schemes which include the provision of services, the settlers on Volta have tended to develop dependent and complaining attitudes. Partly these can be attributed to lack of work and lack of economic opportunity in many of the towns and to the pauperising effects of having to rely upon issues of free food. Partly, too, the settlers, surrounded as they were by evidence of the government's munificence, came to expect to be able to obtain more. Instead of becoming energetic farmers and citizens, those settlers who remained in the towns tended to become apathetic. Much the same has been found on other high-capital welfare schemes (Kontagora in Nigeria; the Western Nigerian Farm Settlements, where even bad weather is said to have been blamed on the government; and the Tanzanian Pilot Village Settlements, among others). The settlers quite correctly come to realise that they can increase their benefits through petition more than production. They play the system. It is not that they are inherently dependent, but that they react to the permissive and relatively well-endowed environment in which they find themselves and demand more, refuse to pay for services and complain and agitate, simply because these approaches bring results.

The chances of avoiding apathy and of achieving secure resettlement may be improved if settlers are presented with an economic environment which is predictable and workable and which they understand. Major innovation, for instance through a controlled irrigation system, can be introduced relatively successfully providing it is regular in its demands, operation and rewards; but to introduce major change-in the Volta case through the proposed mechanised agriculture with some co-operative services and marketing - is to compound the risks 
of a resettlement programme as a whole. With simpler resettlement, less can go wrong. With resettlement which is based upon the administration of a complex economic system the risks are greater and failure leads not only to economic costs but also to social costs in the disillusion, suspicion, inactivity and temporary or permanent migration of settlers. From the point of view of settlers' motivation and performance, it is safer to be simple and to allow settlers to re-establish themselves in familiar surroundings, if possible building their own houses and securing their livelihood in a manner to which they are already accustomed. In this way they can more quickly gain a sense of being settled, and their labour and effort are mobilised without continuing government intervention. The most sure way of achieving self-help is to avoid doing for settlers anything they can do for themselves.

\section{Organisation, Staffing and Style}

When it proved impossible to set up a separate organisation with its own specialist staff to carry out compensation and resettlement, the only course open was to adopt a looser, less hierarchical, less predictable arrangment. The Working Party set up by the Resettlement Officer in May 1962 appeared unsatisfactory because it lacked unity of purpose and cohesion (see pages 38-9). But against this must be set the advantages of informality. Had it been possible to set up an organisation with technical officers responsible to and owing allegiance to the VRA, that organisation might have become a miniature government with rival counterparts to existing government departments. The resulting 'boundary disputes' could have delayed the programme. As it was, the looser arrangement that was perforce adopted avoided this form of confrontation, and placed all the resources of each department potentially at the disposal of the Resettlement Officer, providing he could persuade the head of the department to release them. Again, the departments, working for the VRA on the equivalent of an agency basis, carried out their own administration of staff and technical work, and the VRA was involved only in the planning of the departmental programmes, their co-ordination 
with other programmes and the scrutiny and payment of the costs submitted by the departments. A further advantage was flexibility with staff time, allowing them to start or stop work on resettlement matters with a minimum of administration by the Resettlement Office. Perhaps most important, however, the informal and urgent atmosphere made it easier for many difficult decisions to be taken quickly and with a high degree of consensus. The potential for disagreement and delay over the selection of 52 resettlement sites was enormous, requiring, as it did, the co-operation of soils scientists, agriculturalists, social welfare staff representing the often changeable wishes of the people, geologists, planners and, later, construction staff. That these and many other decisions were taken with an easy give and take and without individuals or departments taking up prepared positions and defending them is of course partly a function of the personalities of the people concerned and of the urgency of the programme; but even so it is difficult to see how else other than through a relatively unstructured meeting like the Working Party so many decisions could have been taken so quickly and so well. When the sites had been selected and the main policies decided, however, the co-ordination of specialists and reaching rapid decisions ceased to be the main activities. Construction took over as the principal focus of the programme, and the Working Party ceased to meet, having completed the bulk of the tasks for which it was appropriate.

It is not easy to assess the extent to which the form and style of a programme may be determined by the specialisms of those whom it is possible to recruit to assist it. Agriculturalists were present at the meetings of 1961 and 1962 , and some of the administrators were economists by training, but it is interesting to speculate whether the agricultural programme might not have been different had it been possible, as was intended, to bring an agricultural economist in on the discussions. Similarly, one may wonder whether the decisions to aggregate the population into 52 resettlements, to resettle the Tongu fishermen and to build the core house might not have taken a somewhat different form had a sociologist, in addition to the Social Welfare staff, been present at the meetings in $196 \mathrm{I}$; for, by the time a sociologist was involved, policy had already begun to set. 
These, however, can be no more than speculative questions, since policy formulation was subject to so many strong pressures, not least the shortage of time. In the event it proved relatively easy to recruit town planners and architects, both from the Department of Town Planning and from the University of Science and Technology, Kumasi, and they were prepared to work hard and imaginatively on the programme. As the symposium papers show, they made major contributions to resettlement. Their presence and enthusiasm shifted the programme towards a higher standard of housing and more detailed planning of towns, and imprinted the resettlement programme with a somewhat more urban style than it might otherwise have had.

Planning. higher standards of housing and the proposed agricultural system had secondary effects through the system of controls which they encouraged, and indeed seemed to require. It must be recognised that, given the limited time and resources available, the architects, planners and construction teams achieved more than might have been expected. The ingenuity of the core house, the skill of the town plans and the towns as built all bear testimony to this. But at the same time the planning involved in housing, towns and also agriculture entailed high costs and a natural pressure towards more and more improvements and controls. The original costings for the core houses were soon raised. When the first houses were built it was intended that the floors should be of rammed earth; but some spare cement was found and used and subsequently, after the cost had been assessed, cement floors were adopted as the norm. Similarly, a cement plaster, not included in the design, was added to the walls. But the better the houses, the more likely it became that strict controls would be exercised over them. Because the core houses were built to a design and made of landcrete instead of mud, settlers were discouraged from developing and extending them as they wished; because the towns had been planned, and paper plans carried authority, spontaneous development was hampered, even though the original planner might in all likelihood have welcomed and encouraged it; and in agriculture, because the programme was meant to be mechanised, agricultural staff took little interest 
in the subsistence production which provided the bulk of the incomes of the settlers. Planning and government intervention created a power structure which gave authority to junior officials who quite understandably exercised much of it in the form of controls and prohibitions, and these were often in danger of hindering rather than helping social and economic development.

\section{OPPORTUNITIES FOR DEVELOPMENT}

Resettlement situations are often regarded as opportunities to introduce social and economic changes. ${ }^{9}$ It is assumed that people who for some reason have been uprooted can be introduced to new social relationships and forms of economic organisation more readily than those who continue to live in a traditional environment. Certainly, lacking accustomed supports as they do and being subject to closer administration than usual, they may be in some sense a captive and dependent population amenable to a degree of persuasion and direction towards a new way of life. Moreover, those responsible for resettlement typically feel a proper obligation to improve the standards of living of the people involved.

However, as was recognised in the Volta operation, displacement from a familiar environment is wounding and those displaced suffer from stress. They seek to discover in their new environments elements with which they are familiar, and in this context the Volta policy of retaining communities intact and attempting to allocate to families homes close to their preferred neighbours must certainly have eased the transition. But insofar as people being resettled are faced with unfamiliar conditions-in housing, in agriculture, in social and political organisation-the stress and insecurity they experience are liable to be greater. There is a conflict here between the aim of re-establishment and rehabilitation which, a priori, can be expected to be most readily (and cheaply) achieved through a transfer to familiar surroundings and a familiar means of livelihood, and measures deriving from a responsible sense of obligation to recompense people for hardship and disruption and to improve their standards of well-being. 
Opportunities for social and economic development are relative in the sense that they can be found almost anywhere, providing adequate and suitable resources are applied to them. The question that has to be asked is what quantum of resources is justified on non-economic grounds, and, for resources additional to that quantum, whether alternative uses would be more beneficial. In practice, a host of factors which are economically adverse tend to recur in resettlement programmes: marginal land (the better land being already farmed), dispersed settlements with poor communications, crises of staff morale, high social overheads, difficulties of devolution of services to local authorities, failures of relatively untried agricultural systems, dependent attitudes among settlers and absenteeism, among others. To differing degrees the Volta resettlement programme has had to face all these difficulties and has been driven to mobilise additional resources to tackle them. For other programmes and projects, if pre-investment economic assessments do not allow for the probabilities of adverse factors such as these applying, over-favourable impressions will be given of the opportunities presented.

Part of the explanation of the frequency with which resettlement operations are regarded as opportunities may lie in the attitudes of government and other organisations to projects and programmes which have a humanitarian rationale or political priority or both. Such projects and programmes often combine substantial resources with a degree of protection from pre- or indeed post-investment economic evaluation. Moreover, resettlement in particular, as with the Volta programme, typically involves manageable administrative units which are relatively easy to inspect and supervise. They are more readily presented as direct evidence of achievement than other more diffuse programmes. In different ways the Volta resettlement operation illustrates these tendencies: it provided an opportunity for social welfare workers to change people's attitudes and improve their living standards, for architects to design housing and amenities, for planners to prepare town layouts, for agriculturalists to introduce a new system of agriculture. To all of these, resettlement meant a professional challenge and a promise of resources to meet it. 
One aspect of the opportunity of a resettlement programme may therefore be availability of resources and administrative conditions for the implementation of specialist and departmental programmes which might otherwise not be acceptable. Had the original agricultural proposals for Volta not been linked with resettlement, with its strong humanitarian rationale combined with the need for more intensive farming to provide a livelihood off less land than before, they might have been exposed to a searching economic and administrative preinvestment analysis which would have pointed to the probability of failure. As it was, the nature of the resettlement programme probably made it easier for the Ministry of Agriculture to obtain funds for mechanised agriculture with co-operative services than it would have been for a programme unrelated to resettlement. Thus, from a departmental point of view, one criterion of a programme may be the ease with which a Treasury or a Ministry of Finance can be persuaded to part with funds. From a national point of view, the issue is, of course, whether those funds might not be better applied in some other way. It is open to question whether, with major humanitarian programmes which have high priority, the opportunity perceived may not often be rather more for departments and organisations than for national social and economic development.

\section{Timing and Costs}

One of the most important questions raised by the Volta resettlement experience concerns the relationship between pressure of time and costs. Although the shortage of time for most of the policy-reformulation and implementation before the flood (little over two years from May I 962 to mid-1964) appears extreme, it is common for there to be pressures for speed in the early stages of settlement schemes. The lessons of Volta in this respect may, therefore, apply widely.

It has to be recognised that there were substantial advantages in the pressure of time. It compelled surveyors to abandon inappropriately exact methods of measurement, made the resources of some departments available for what was recognised as likely to be only a short period and not a long-drawn-out 
commitment, prevented decisions about townsites becoming major interdepartmental issues, and gave the Social Welfare workers a sense of urgency which they passed on to the people. Crisis was a catalyst to communications, facilitating a rapid flow of information between the principal officers concerned and, for the construction and evacuation operations, driving them into setting up radio links between Accra and the field. Without the energy, impatience and priority generated by the emergency, it would certainly have taken longer to thread through the red tape of government regulations for such purposes as obtaining import licences for machinery and cement. Parkinson's law worked in reverse: tasks were tailored to fit the short time available; as those involved worked for longer hours, time was in a sense expanded; and they worked harder than might normally have been expected of them. Consequently, staff salary overheads were lower in relation to output than they would probably have been if work had been spread over a longer period. In ways such as these, urgency was an asset, saving costs and improving performance.

On the other hand, the speed of policy-reformulation and implementation from 196 I to 1964 led to heavy costs, which would probably have been lower had more time been available. In the first place, time did not allow a full pilot settlement with optimum feed-back to policy-making. The first settlement town, Nkwakubew, was an effective pilot to the extent that house construction was tried out there, and it was established that the Field Technical Unit of the Department of Social Welfare would not be able to undertake the construction programme as a whole. But as other findings emerged from Nkwakubew, concerning for example settlers' expectation of a house for each wife and Tongu absenteeism to go fishing, it was already late to allow them to influence policies. Again, had there been time to test the proposed housing for user satisfaction, small adaptations might have been introduced to make them more acceptable.

Secondly, shortage of time was a major, perhaps the principal, factor responsible for shortcomings in the co-ordination and performance of activities. The sequence of activities was at several points telescoped, so that later activities had to be begun 
before antecedent activities on which they depended had been completed: for instance, valuation and social surveys had to be undertaken before the demarcation of the lake boundary was complete; and planning the settlements had sometimes to be carried out before social survey information had been processed. More seriously, in the long term, the high priority necessarily given to site-selection, construction and evacuation meant a lower priority for other activities which were consequently omitted or delayed. In the political climate of Nkrumah's Ghana, it was possible to assume that the acquisition of land for the resettling communities would not require major administrative and legal processing; and, given that time anyway did not permit legal acquisition, it made administrative sense to go ahead without it. In the long term, however, the repercussions when the owners of much of the land reasserted their rights gravely weakened the agricultural programme and threatened the viability of many resettlement towns. Again, when activities competed for the same resources, those with immediate, short-term and humanitarian purposes took priority over those with longer-term, usually economic, implications. This, of course, affected the way in which senior officials distributed their work loads, but the most damaging example that can be readily identified was the clearing programme for agriculture. There was straight competition between the construction and agricultural programmes for the use of heavy clearing equipment, and clearing townsites for construction necessarily and sensibly took priority. Later, however, this meant that not enough land had been cleared for agriculture and the agricultural programme was delayed and hamstrung. In these ways pressure of time contributed to loading the resettlement programme with long-term liabilities.

The difficulty of tackling these liabilities was itself exacerbated by a third effect of the urgency of the earlier stages of resettlement. The level of performance achieved before and during the main evacuation could not possibly be maintained. After 1964 there was no longer the advantage of an inexorable deadline of dam closure. It was less immediately demanding, though in fact at least as difficult, to administer the new towns and to promote mechanised agriculture than it had been to 
carry out construction and evacuation. Communications reverted to the standards of slowness to be expected, given the physical conditions of the basin. Whereas funds and equipment had been available during the emergency, they tended to dry up afterwards. The case had to be argued each financial year for allocations for the house-completion programme. The heavy equipment was sold off, halting the clearing of land for agriculture. It was difficult for staff to avoid a degree of demoralisation. Had there been less of an emergency earlier, there might in the post-resettlement phase have been less of a sense of anticlimax.

If these are the principal benefits and costs of urgency (and they are by no means all), it appears on balance that the financial costs of resettlement and agriculture in the long term would probably have been less had there been less pressure of time. But such a statement involves an implied assessment of what would have happened had there been more time, and it is always possible that this would have meant a more elaborate and expensive approach. Certainly, the case for a pilot project with settlers and for an ordered sequence for the performance of necessary activities is strong, but so is the case for shortcuts dictated by shortage of time. What can perhaps be said is that the optimum degree of urgency probably lies somewhere between the Volta situation, where a major activity (land acquisition) was omitted and another (land clearing) was seriously delayed and incomplete, and the Tema situation, where prolonged political pressure had time to force the level of amenity and service, and hence costs, upwards. But to discuss timing and costs in isolation beyond this point without considering other factors and how they impinge on decision-making would be misleading; for time is only one of the resources involved.

\section{Gonstraints and Ghoiges}

With the benefit of hindsight denied to those who planned and executed resettlement and wrote the symposium papers, it is possible to see advantages in some alternative measures which might well be considered in other resettlement programmes. The construction of housing in traditional or at any rate 
simpler materials might have reduced costs, allowed more rooms per family, encouraged settlers to build extra rooms on their own initiative, and reduced or removed the need for continued housing administration. The provision of compensation to fishermen and some farmers in economic assets-nets and boats, or tools, roads and marketing services-might have reduced costs and might at the same time have helped fishermen to exploit the increased fish population in the lake and farmers to open up new areas to cultivation. A concentration of administrative resources on land acquisition and of agricultural resources on ensuring that settlers were quickly self-supporting for their subsistence needs might have reduced absenteeism, limited the growth of dependent attitudes among settlers, restrained the growth of agricultural bureaucracy, and avoided some of the loss of morale entailed in the failure of the programme for mechanical cultivation. All these points are, of course, arguable, and actors and observers would wish to challenge some or all of them. But whether they are accepted or not, they raise the vital and fundamental question, which rarely receives the attention it deserves, of to what extent in practice choices of policy are effectively open.

Any short answer to this question is bound to be misleading. Many factors are involved. One determinant is the physical problem to be tackled. Another is the amount of information available on which policies can be based. Yet another is the point in time which is taken for the assessment of the feasibility of options. But besides these and others, the Volta resettlement experience presents a sequence of situations in which five constraints, all interrelated, appear to be dominant in setting the bounds within which decisions could realistically be made; and these may apply widely elsewhere.

The first is time. There is no need to elaborate the interpretation developed earlier (in the Introduction) that extreme pressure of time alone ruled out the self-help with incentives policy recommended by the Preparatory Commission. The delays of 1961 and of the first five months of 1962 severely restricted room for manoeuvre in choosing between policies. Drastic simplifications in housing and compensation were difficult to avoid. Furthermore, the urgency of the timetable 
reduced the scope even for identifying what the alternatives might be, for instance by making it difficult for specialist advice to be assessed with any possibility of rejection.

The second, closely linked, constraint is administrative resources. Given limited personnel and time, the operational capacity of resettlement staff was limited. Reduction in numbers of decisions, simplification and standardisation were unavoidable. The policies of resettling the Tongu fishermen, of reducing siting negotiations and decisions by collecting together the 730-odd communities into fewer larger units, and of standardising housing instead of varying it according to local customs and needs, if not dictated by a need to economise in using scarce administrative resources, were at least strongly influenced by it. Similarly, until the acceptance in I968 that WFP $35^{6}$ would treat settlements as individual cases, the resettlement towns, different though they were in size, ethnic composition, political relationships with the host communities and availability of land, tended to be subject to the same controls and to receive similar staffing and services. Had other constraints remained the same, more administrative resources would have been needed to implement a policy of official resettlement involving greater differentiation unless, of course, decisions had been left to the settlers themselves.

A third constraint, more elusive but nonetheless important, is the political environment. The simplest and cheapest forms of resettlement have usually been adopted either under colonial governments where civil servants were not subject to political pressures or in refugee situations where the settlers are usually politically weak. The Volta resettlement programme differed from these in that there was a strong sense of obligation to the people affected, a sense that they deserved special recompense for the loss and disruption inflicted on them for the benefit of Ghana as a whole, and in that officials were exposed to the likelihood of public criticism by the settlers' articulate representatives. ${ }^{10}$ Moreover, the resettlement programme was the more sensitive because of the international attention attracted by the Project as a whole, and this may have indirectly influenced the tendency to agree that the towns should be modern and model. Departmental pressures, too, as we have seen, were 
for a more expensive programme. In these circumstances, it may be doubted whether a simpler form of resettlement could have been sustained had its adoption been recommended.

A fourth constraint is finance. The options considered to be open in 196 r were limited by the $£ 4$ million ceiling. Later, as savings on the dam construction programme became available, this constraint was relaxed, allowing the new policy to be adopted. In general, with high priority programmes, finance may indeed be the resource that is most easily expanded.

At any point in time, a fifth constraint can also be identified in the extent of existing commitment. The government statement that no one would be worse off as a result of the dam was heavily committing in eliminating a wide range of policies in which some people might have been considered likely to be worse off, and pointed the programme in the direction of higher expenditure and more lasting involvement. The construction of towns, the provision of higher standard housing in permanent materials, the services installed in the towns, the 400 tractors that were launched on the agricultural programme-these were all committing, establishing physical entities on the ground, arousing expectations among the people, drawing after them an acceptance of responsibility on the part of officials and organisations and reducing flexibility for the future. When problems were encountered, as most conspicuously with denial of access to land, there was consequently a proper sense of responsibility to do something about them. But the more was done, the more had to be done. To undertake withdrawal of special administration of the towns or of the agricultural programme would in these circumstances have proved quite as difficult a task as any in the whole history of resettlement.

In other resettlement programmes, and perhaps in development projects in general, the extent to which there are choices to be made can be expected to be related to these five factors. It is not just that different policies make different demands on resources, but that the resources available and the commitments undertaken close off potential options. As suggested in the Introduction, time, administrative resources and the political climate combined to eliminate the possibility of self-help resettlement with incentives. In fact, without these five conditions 
- a reasonable time span, adequate administrative capacity, political support, sufficient finance and an absence of prior commitments - a choice of policy, whatever the appearances, may simply not be open. As with the Volta resettlement programme in May 1962, there may be very little room for manoeuvre. If there is any lesson that stands out from the Volta resettlement experience, it is the importance, not just of mobilising and being aware of alternatives, but of ensuring conditions, particularly enough time, in which there is a choice to be made between them.

\section{CONGLUSION}

It will not be difficult for future visitors to some of the resettlement towns to be critical of aspects of the programme. The ease of criticism is, however, partly a function of the free discussion and open-handed sharing of information which has characterised the resettlement programme and which has made this book possible. It has to be remembered, too, that there would have been trenchant criticisms whatever the policies pursued. Had the political climate and other factors allowed cheaper, simpler resettlement in mud and thatch houses, many voices, including no doubt those of visiting experts, would have been raised against the wasted opportunity for improvement. Had resettlement not been provided for the Tongu fishermen, there would have been an outcry against neglect of obligations and allegations of discrimination. Any critic will be well advised to think back to May 1962 and wonder what he would have done had he been Resettlement Officer. He may well be driven not to an adverse assessment of what was done but to concluding that one of the greatest lessons of the Volta resettlement experience is the importance of preventing situations like that of May 1962 ever arising in the first place.

Whatever the future of the towns and of the attempts to retrieve something from the agricultural programme, whether the towns become flourishing centres or ghost towns, or whether as seems more likely their development is mixed and does not fit into simple categories of success or failure, the Volta resettlement operation will stand as a brave and imaginative attempt 
with limited resources to tackle a challenging and urgent crisis. It should not be judged only in terms of the multiple problems which have assailed the resettlement operation or of the failure of the programme of mechanised agriculture. It should also be seen as a highly successful operation in which a large, poor population, scattered over an extensive and inaccessible area, and overtaken by an emergency which destroyed their livelihood and threatened their lives, were rescued and provided with shelter and food.

It is well to end with a note of warning. The transfer of experience from one environment to another is difficult and full of risks. Measures which work in one situation may prove useless in another. Politicians, planners and civil servants faced with resettlement programmes in other parts of the world will want to draw their own conclusions and prescriptions from the Volta experience. In doing this, there is one final factor which they should bear in mind. Ghana was well-endowed in the dedication and energy of those who planned and carried out the tasks of evacuation and construction. The Ghanaians who prepared the people for the move and then moved them, and those-Ghanaians, Canadians and others-who carried out the surveys, planning and construction, achieved levels of performance which could not easily be duplicated. Such service certainly cannot be taken for granted, and any government which can call on it is to be counted fortunate.

\section{REFERENCES}

I. S. N. P. Lyimo and J. D. Msele, "Report on the Construction of Unauthorized Structures in New Ajena", mimeo, August I 5,1964 , p. I.

2. Much of the information in this section is derived from Rowena M. Lawson, "An Interim Economic Appraisal of the Volta Resettlement Scheme", The Nigerian Journal of Economic and Social Studies, Vol. Io, No. I, March 1968, pp. 95-109.

3. The breakdown was 300 Massey Ferguson 165 s, roo Massey Ferguson $135 \mathrm{~s}$, 300 ploughs, and much other ancillary equipment. Rowena M. Lawson, "An Interim Economic Appraisal of the Volta Resettlement Scheme, Ghana", mimeo, paper to a 
symposium of the African Studies Association of the United Kingdom, September 22, 1967, p. 6.

4. See, for instance, Report of the Committee of Enquiry on the Local Purchasing of Cocoa, Ministry of Information, Accra I966, passim.

5. "Report of the WFP Mission on the Appraisal of the Volta River Resettlement in Ghana in regard to WFP Assistance", mimeo, FAO, Rome, April 18, 1967, p. 31 .

6. Figures from a communication from the Ghief Executive, vRA, May I9, Ig6g.

7. The scale of these problems can be judged from the fact that, at the end of $1967,5,009$ petitions and complaints were reported to have been received. Volta River Authority Report for the Year 1967, Volta River Authority, Accra 1968, p. 19.

8. David Butcher and Laszlo Huszar (edited by Tudor G. Ingersoll), Bui Resettlement Study, a Report for the Ministry of Fuel and Power, prepared in the Research Department, Faculty of Architecture, University of Science and Technology, Kumasi, February 1966, p. 5 .

9. See, for instance, David Brokensha and Thayer Scudder, "Resettlement", in N. Rubin and W. M. Warren, eds., Damis in Africa, an Inter-disciplinary Study of Man-Made Lakes in Africa, Frank Cass, London I 968, pp. 20-62, especially pp. 22-3 ('population relocation presents an exceptional opportunity to improve the standard of living of those involved as well as to contribute to national development').

ı. On February ı6, I g66, for example, a whole morning in the National Assembly was devoted to a private member's motion requesting the government to speed up the development of the Volta resettlement areas. National Assembly, Parliamentary Debates, Vol. 43, No. i I, February i6, I 966, columns 517-54. 


\section{BIBLIOGRAPHY}

Since some readers will also be interested in the hydro-electric and industrial aspects of the dam, a few references to relevant published works are included. The great majority of entries are, however, in whole or in part directly concerned with the Volta resettlement programme. Although they have not been included, the files, reports and memoranda of the Resettlement Office of the VRA are an important source and a most valuable archive which it is to be hoped will be preserved for future research. Readers who are aware of additional or subsequent published or unpublished work on the Volta resettlement operation are invited to write with full details to: The Librarian, Volta River Authority, P.O. Box M.77, Accra.

\section{A. Published Books and Articles}

Amarteifio, G. W., "Human Aspect of the Volta Resettlement", Financial Times, February 24, I969; and Butcher, D. A. P. and Whitham, David, Tema Manhean, a Study of Resettlement, Planning Research Studies Number Three, published for the University of Science and Technology, Kumasi, by Ghana Universities Press, Accra 1966, $97 \mathrm{pp}$.

Anon., "Resettlement on the Volta" (a series of three articles), West Africa, No. 2347, May 26, I962, p. 563; No. 2348, June 2, I 962, p. 595; and No. 2349, June 9, I962, p. 623.

Anon., "Resettlement on the Volta" (a series of four articles), West Africa, No. 2481, December 19, I964, p. I415; No. 2482, December 26, 1964, p. I 445; No. 2483, January 2, 1965, p. 7; and No. 2484 , January 9 , I 965 , p. 35 .

Anon., "Fighter on the Volta", West Africa, No. 2486, January 23, 1965, p. 85.

Anon., "Volta Resettlement Symposium", Ekistics, Vol. 21, No. 124, March 1966, pp. I49-63 (an abstract of the Volta Resettlement Symposium papers).

Anon., "Waiting for Valco", West Africa, No. 2586, December 24, I 966 , p. 1475 .

Barnes, Kwamina, Economics of Volla River Project, University Bookshop, Legon 1966.

Brokensha, David, "Volta Resettlement and Anthropological 
Research", Human Organization, Vol. 22, No. 4, I963, pp. 286-9o; and Scudder, Thayer, "Resettlement", in Neville Rubin and William Warren, eds., Dams in Africa, Frank Cass, London 1968, pp. 20-62.

Butcher, David and Huszar, Laszlo (edited by Tudor G. Ingersoll), Bui Resettlement Study, a Report for the Ministry of Fuel and Power, prepared in the Research Department, Faculty of Architecture, University of Science and Technology, Kumasi, February 1966. Chambers, Robert, Settlement Schemes in Tropical Africa, a Study of Organisations and Development, Routledge and Kegan Paul, London I 969; Praeger, New York i 969.

Danby, Miles, "Problems of Resettlement in Africa", Proceedings of the Philosophical Society for the Sudan, Fourteenth Annual Conference, in conjunction with the Sudan Engineering Society, December 6-9, I 966 , Kinartoum, pp. I58-67.

Dobson, F. J., "Volta River Project: Problems of Resettlement", Ghana Trade Journal, No. 43, December 1962, pp. I 2-13 and I8. du Sautoy, Peter, "Resettlement Schemes and Community Development", Community Development Bulletin, Vol. I2, March 196ı, pp. $12 \mathrm{I}-3$.

Edgcomb, Gabrielle, Man-Made Lakes, a Selected Guide to the Literature, National Academy of Sciences, National Research Council, Washington DC, September I, 1965 .

Harrison Ghurch, R. J., "A Geographical View", in Neville Rubin and William Warren, eds., Dams in Africa, Frank Cass, London I $968, \mathrm{pp} . \mathrm{I}-\mathrm{I} 2$.

Hilton, T. E., "The Fisheries of the Volta System in Ghana", Oriental Geographer, Vol. 5, No. I, I96I, pp. 21-34; "The Volta Resettlement Project", Fournal of Tropical Geography, Vol. 24, June 1967, pp. I2-21.

Hopkins, A. G., "Volta Resettlement Symposium", Journal of Modern African Studies, Vol. 3, No. 2, August 1965, pp. $292-4$.

Huszar, L., "The Volta Resettlement Scheme", Fournal of the Town Planning Institute, Vol. 5I, No. 7, July-August I965, pp. 279-82. Jones, L. Rouse, "Legal Problems of the Volta Dam", in Neville Rubin and William Warren, eds., Dams in Africa, Frank Cass, London 1968, pp. 76-89.

Jopp, Keith, Volta, Volta River Authority, Accra 1965.

Killick, Tony, "The Volta River Project", in Walter Birmingham, I. Neustadt and E. N. Omaboe, eds., A Study of Contemporary Ghana; Vol. I: The Economy of Ghana, Allen and Unwin, London I 966 , pp. 39I-41 0 . 
King, John A., Jr., Economic Development Projects and Their Appraisal, Cases and Principles from the Experience of the World Bank, Johns Hopkins, Baltimore I967, pp. I 28-55, "Case 6. Ghana: The Volta River Project".

Kudiabor, G. D. K., "Volta Resettlement Planning and Development: The Regional Gontext", Ghana Trade Journal, August I965.

Lawson, G. W., "Volta Basin Research Project", Nature, No. 199, August 31, 1963.

Lawson, Rowena M., "The Structure, Migration and Resettlement of Ewe Fishing Units", African Studies, Vol. I 7, No. I, I958, pp. 2 I-7; "The Development of the Lower Volta", The Economic Bulletin of Ghana, Vol. 7, No. 4, I963, pp. 81-90; "The Economic Organisation of the Egeria Fishing Industry on the River Volta", Proceedings of the Malacological Society, Vol. 35, Part 6, December I 963, pp. 273-87; "An Interim Economic Appraisal of the Volta Resettlement Scheme", The Nigerian Fournal of Economic and Social Studies, Vol. I0, No. I, March 1968, pp. 95-I09; "The Volta Resettlement Scheme", African Affairs, Vol. 67, No. 267, April I 968, pp. 124-9.

Moxon, James, "On a Slow Boat to Krachi", Daily Graphic (Accra), December 6, 1965; and "The New Kete Krachi", Daily Graphic, December 13, 1965; Volta: Man's Greatest Lake, Deutsch, London 1969; Praeger, New York I969.

Ollennu, N. A., Principles of Customary Land Law in Ghana, Sweet and Maxwell, London 1962; "Aspects of Land Tenure", in Walter Birmingham, I. Neustadt and E. N. Omaboe, eds., A Study of Contemporary Ghana; Vol. 2: Some Aspects of Social Structure, Allen and Unwin, London 1967, pp. 25I-66.

Rubin, Neville and Warren, William, eds., Dams in Africa, an Interdisciplinary Study of Man-Made Lakes in Africa, Frank Cass, London I 968 .

Scudder, Thayer, "Man-Made Lakes and Population Resettlement in Africa", in R. H. Lowe-McConnell, ed., Man-Made Lakes, Proceedings of a Symposium held at the Royal Geographical Society, London, on 30 September and I October I 965, Academic Press, London 1966, pp. 99-108.

Steel, Robert W., "The Volta Dam: Its Prospects and Problems", in Neville Rubin and William Warren, eds., Dams in Africa, Frank Cass, London i 968, pp. 63-75.

Tamakloe, Martha A., "New Mpamu: Case Study of a Volta River Authority Resettlement Town", Ghana Fournal of Agriculture Science, Vol. I, No. I, June I968, pp. 45-5I. 
Whetham, Edith H., Co-operation, Land Reform and Land Settlement: Report on a Survey in Kenya, Uganda, Sudan, Ghana, Nigeria, and Iran, The Plunkett Foundation for Co-operative Studies, London I968, especially pp. $3^{8-42}$.

B. Government Publications

(In chronological order)

Public Lands Ordinance, Cap. 134, Laws of the Gold Coast.

Stool Lands Boundaries Settlement Ordinance, Cap. 139, Laws of the Gold Coast.

Public Lands (Leasehold) Ordinance, Cap. 524, Laws of the Gold Coast.

William Halcrow and Partners, Report on Development of the River Volta Basin, Alliance House, London, for the Government of the Gold Coast, August 15, I 95 I.

Development of the Volta River Basin, a Statement by the Government of the Gold Coast on the Volta River Project and Related Malters, Government Printing Department, Accra I952.

Pogucki, R. J. H., Report on the Preliminary Survey of Land Tenure in the Volta River Basin, Government Printer, Accra 1955.

The Volta River Project, Vol. I: Report of the Preparatory Commission, HMso, London I956, I $35 \mathrm{pp}$; Vol. II: Appendices to the Report of the Preparatory Commission, HMso, London I956 (especially pp. $65^{-1} 35$ for Appendix vi: The Effects of the Project in the Area Subject to Inundation), $475 \mathrm{pp}$.

The Volta River Project, Statement by the Government of Ghana, 2oth February rg6r (White Paper No. I of I 96I), Government Printer, Accra I96.

The Volta River Project, A Statement by Osagyefo Dr. Kwame Nkrumah, President of the Republic of Ghana, to the National Assembly, February 2Ist, I96I, Ghana Information Services, Accra.

Annual Report of the Department of Social Welfare and Community Development, Ig6I (and subsequent reports), Government Printing Department, Accra I963.

Volta River Development Act $196 I$, Act 46 , Government Printer, Accra I $96 \mathrm{I}$.

The Volta River Project, Statement by the Government of Ghana (White Paper No. I of 1962), Government Printer, Accra 1962.

Administration of Lands Act 1962, Act 123, Government Printing Department, Accra I 962.

State Lands Act 1962, Act 125, Government Printing Department, Accra I 962 .

Agency for International Development, Report on, Soil and Agricultural 
Survey of Sene-Obosum River Basins, Ghana, East Brong-Ahafo and Ashanti Regions, Department of State, Washington DC, June I962.

Volta River Authority, Problems of Resettlement, mimeo, I963, 5 pp. Volta River Authority, Some Facts about Resettlement, 1963, 4 pp.

Volta River Authority Report for the Year 1962 (also for 1963 , 1964, 1965 and r 966), Volta River Authority, Accra.

Boyle, W. Dean and Kuhns, Buford E., Evaluations, Suggestions and Recommendations on the Program of the Volta River Authority for Resettlement of the People in the Area to be Inundated by Construction of the Volta River Dam, Ghana, submitted by the United States Department of the Interior, Bureau of Reclamation, to the United States Agency for International Development, November i 963 , $43 \mathrm{pp}$.

Seven-Year Plan for National Reconstruction and Development, $1963 / 1964_{-}^{-}$ 1969/r97o, Government Printing Department, Accra 1963-64.

Public Conveyancing Act 1965, Act 302, State Publishing Corporation, Accra-Tema 1965.

Ministry of Social Welfare and Community Development, Ghana, "Volta River Resettlement: a Selection of the Symposium papers", Advance, No. 47, July I 965 .

Djan, M. T., "Volta River Project Resettlement Areas", Private Member's Motion in the National Assembly, Parliamentary Debates (Ghana), Vol. 43, No. II, February i6, 1966, pp. 51754 .

Volta River Development Act Ig6I (Amendment) Decree, I967, NLCD 2 I I, State Publishing Corporation, Accra-Tema 1967.

State Lands Act 1962 (Amendment) Decree, 1968, NLCD 234, State Publishing Corporation, Accra-Tema 1968.

\section{G. Some Unpublished Sources}

Abbreviations: For VRSP see entry under "Volta Resettlement Symposium Papers"; vRA stands for Volta River Authority.

Akuoko, E. A. K., "Legal Rights in Resettlement Properties", VRSP, pp. I $57-65$.

Alasco, J., "Proposal for a Programme Control System for Volta River Authority Resettlement Operation", mimeo, vRA, Accra I 963 .

Amarteifio, G. W., "Social Welfare", vrsp, pp. 38-85.

Barnes, K., "A Study of the Financial and Economic Consequences of the Volta River Project. Part I-Existent Rural Economy of the Inundated Volta Basin", Volta Basin Research Project Technical Report No. x4, University of Ghana, Legon 1964 . 
Brokensha, David, ed., "Volta Resettlement, Ethnographic Notes on Some of the Southern Areas", mimeo, Department of Sociology, University of Ghana, Legon, April I 962.

Butcher, D. A. P., "The Role of a Behavioural Scientist in the Volta Resettlement Scheme", typescript, c. I962; "Volta River Project Resettlement Social Survey Analysis Instructions", mimeo, University of Scicnce and Technology, Kumasi, c. I962; "Kete Krachi", mimeo, University of Science and Technology, Kumasi I962; "Social Survey", vRsP, pp. 28-37; and Amarteifio, G. W., "Volta River Project Resettlement Survey Tables", typescript, Research Department, Faculty of Architecture, University of Science and Technology, Kumasi, and Resettlement Office, vra, Accra, June 1967.

Cochrane, T. W., "Preliminary Bibliography of the Volta River Authority Programme", mimeo, vRA, Accra, January 1968.

Danby, Miles, "House Design", vRsP, Pp. I 10-30.

Department of Sociology, University of Ghana, Legon: Field work studies reports in typescript, submitted by Social Welfare students under the supervision of Mrs P. W. Jones-Quartey:

Aboah, J. E., "The Administrative and Social Problems of Adjustment in the New Dunyo Vakpo and Wusuta Resettlement Towns, Volta River Project", September I965.

Agbodzi, F. M. and Kuhler, C. M. K., "Dunyo-Vakpo Volta River Resettlement Survey", 1967.

Aikins, F. K. O., "vra Dam Resettlement Scheme and the Nangodi Project", I966.

Asamany, H. K. and Timbila, A., "Report on vRA Dam Resettlement Scheme", 1967.

Asiedu, E. M., "Volta River Resettlement Scheme", I966.

Gyampoh, N. S., "Volta River Authority (Resettlement)", September 1963 .

Pongo, H. H. and Dzadey, F. A., "Survey of Tepo Resettlement", I967.

Quashigah, S. M. Y., "Resettlement-Vakpo, Wusuta, Danyigba and Peki Todome", ig66.

Salawu, R. D., "Volta River Resettlement-Kpando Fesi, Nkonya Tepo and Nkonya Wurupong", ig66.

Williams, J. K., Essiedu, E. M. and Fletcher, V. E., "Report on Resettlement-Nkwakubew", 1966.

Dobson, F. J., "Introductory Paper", vRsP, pp. I-8.

Dodoo, Martha A., "Case Study of a Resettlement Town: New Mpamu", vRSP, pp. 139-46. 
Fewings, B. T., "Plan for Kete Krachi New Town", mimeo, University of Science and Technology, Kumasi I g62, I I pp.

Huszar, Laszlo, "Afram Area Plan", University of Science and Technology, Kumasi, January ig63; "Resettlement Planning", vRsP, pp. IO0-9; "Revised Proposals for the Town Manager's. Handbook", December ig64.

Johnson, T. S., "Paper on Engineering Problems", vRsP, pp. I3 I-8. Kalitsi, E. A. K., "Organisation and Economics of Resettlement", VRSP, pp. 9-27; "Present and Future Problems of Administering Resettlement Towns", vRsP, pp. 20o-6.

Kudiabor, G. D. K., "Planning for Balanced Social, Economic and Physical Development-Ghana Volta Basin", unpublished M.A. thesis, University of British Columbia, Vancouver, I963; "The Town Manager's Handbook", I 964; "Post-Resettlement Problems on Resettlement Sites", mimeo, Town and Country Planning Division, Accra I 964 .

Lawson, Rowena M., "An Interim Economic Appraisal of the Volta Resettlement Scheme, Ghana", mimeo, paper to a symposium of the African Studies Association of the United Kingdom, September 22, 1967, I6 pp; "Processes of Rural Economic Growth, a Case Study of the Change from a Static to a Transitional Economy in the Lower Volta of Ghana, 1954-1967", Volta Basin Research Project Technical Report No. x27, University of Ghana, Legon I $968,88 \mathrm{pp}$.

Lyimo, S. N. P. and Msele, J. D., "Report on the Construction of Unauthorized Structures in New Ajena", mimeo, August I5, I $964,22 \mathrm{pp}$.

"Materials on the Social Survey", mimeo, Resettlement Office, VRA, undated, I4 Pp.

Nicholas, M. S. O., "Paper on Heavy Forest Glearing Experiences in the Volta River Authority", mimeo, vRA, Accra, undated; "Resettlement Agriculture", vRSP, pp. 86-99; "Nkwakewbew Settlement", mimeo, vRA, Accra I96I; revised August I964, VRA, Accra 1964 .

"Plan of Operations Agreed upon between the Government of Ghana and the United Nations/FAo World Food Program concerning Assistance for the Volta River Land Clearing and Settlement (Project No. 356)", mimeo, December ig67, io pp.

Quartey, E. L., "Industrial and Commercial Opportunities and the Volta River Dam" (speech delivered at a symposium at the State House, Accra, on February 9, 1967), mimeo, vRA, Accra ı 967 . 
"Report of the WFP Mission on the Appraisal of the Volta River Resettlement in Ghana in regard to WFP Assistance" (The Wilbrandt Mission Report), mimeo, FAo, Rome, April i8, I967, $65 \mathrm{pp}$.

"Request to the UN/Fao World Food Program for Assistance in a Project for Economic and Social Development-Volta River Land Clearing and Settlement wFP 356", mimeo, presented by the Ghana Government, June I967, I9 pp.

"Revised Village Groupings", published by the Social Survey Section, vRA: Ist revision, August 31,1964 ; 2nd revision: February 27, 1965; 3rd revision: March 31, 1968.

Rugg, Robert D., "Reservoir Resettlement in Africa", unpublished M.A. dissertation, Department of Geography, Chicago University, June 1967 .

Russell, A. C., "Volta River Survey: a general statement of the effect which the existing law relating to African land tenure will have on the proposal to dam the River Volta at Ajena and flood large areas of the Volta Basin", mimeo, Cape Coast I95I.

Sagoe, K. Amanfo, "Valuation, Acquisition and Compensation for Purposes of Resettlement", vRsP, pp. I66-99; "Teleology of Recent Land Legislation in Ghana", paper submitted to the Fao/ECA Development Centre on Land Policy for West African Countries, I963 (Part 3 concerns land legislation as applied to the Volta resettlement scheme).

Schram, John, "A Study in Social Anomie and Retreatism at a Resettlement Site", typescript, Institute of African Studies, University of Ghana, Legon 1967, 20 pp.

Snaggs, Ken, "East Volta Plan", Town and Country Planning Division, Accra, November 1962.

Tetteh, P. Austin, "Report on a Preliminary Social Survey of Kete-Krachi", mimeo, Office of the Town Planning Adviser, Accra, April 1956, 43 pp.

Thompson, H. E., "Asikuma-Nkwakobio Resettlement ProjectBrief Notes", mimeo, vra, Accra, c. I962, ro pp.

Town and Country Planning Division, Accra, "Model Building Regulations", 1960.

Town and Country Planning Division, Accra, "Volta Basin Plan", June 1962.

"Village Groupings", mimeo, published by the Social Survey Section, vRA, January 31 , 1964 .

"Volta Lake Basin Area Development Plan", mimeo, undated but c. $19^{6} \mathrm{I}$. 
"Volta Resettlement Symposium Papers", papers read at the Volta Resettlement Symposium held in Kumasi, March 23-27, I965, mimeo, VRA, Accra, and Faculty of Architecture, University of Science and Technology, Kumasi 1965.

Volta River Agricultural Resettlement Unit, "Volta River Resettlement Land Clearing Project: un/FaO World Food Programme Project 356-Brief General Information", mimeo, VRA, Accra (ref. no. VRA/RR. 2/42), 23 pp.

Warmann, J. St. G., "Public Health Problems of Volta Resettlement", vRSP, pp. 147-56.

Welch, J. D. and Nicol, J. F., "Thermal Comfort and Physical Conditions in Old and New Anyaboni, Preliminary Report for the Volta Resettlement Symposium", mimeo, Faculty of Architecture, University of Science and Technology, Kumasi 1965. 